\title{
Evaluating the influence of building fabric, services and occupant related factors on the actual performance of low energy social housing dwellings in UK
}

\author{
Rajat Gupta, Mariam Kapsali and Alastair Howard \\ Low Carbon Building Research Group, Oxford Institute for Sustainable Development, School \\ of Architecture, Oxford Brookes University, Oxford, rgupta@brookes.ac.uk
}

\begin{abstract}
This paper empirically investigates the influence of building fabric, services and occupant related factors on actual energy use of six case study dwellings, located in three new low energy social housing developments in UK, covering a variety of built forms and construction systems (timber frame, hempcrete, steel-frame). Physical monitoring of indoor environment and window-opening is cross-related with building fabric and systems' performance, and qualitative data gathered through occupant surveys, review of control interfaces and handover guidance, to understand the causes of the gap between modelled and measured energy use. Actual energy use is found to exceed design expectations by a factor of three, questioning the need for whole-house mechanical ventilation heat recovery (MVHR) systems at measured air permeability rates of $6 \mathrm{~m}^{3} /\left(\mathrm{h} \cdot \mathrm{m}^{2}\right)$ against the design target of $3 \mathrm{~m}^{3} /\left(\mathrm{h} \cdot \mathrm{m}^{2}\right)$. Lack of proper commissioning of MVHR and heating systems, combined with inadequate user comprehension about their operation and control leads to occupant 'misuse' wherein systems are de-activated, thereby negatively affecting indoor air quality. This is confounded by occupant factors related to higher demand temperatures, unexpected opening of windows during winters due to under-performance of MVHR combined with habitual behaviours, and over-use of heating systems to compensate for higher than expected air permeability.
\end{abstract}

Key words: social housing; energy; environment; building performance evaluation; occupant behaviour

\section{Introduction}

In the UK, as with other European countries, about $27 \%$ of all carbon dioxide $\left(\mathrm{CO}_{2}\right)$ emissions are related to energy use in housing (DCLG, 2009; EU, 2011; HMG, 2008). The housing market has seen an exponential development of policy culminating in energy certificates, in line with the EU Energy Performance of Building Directive (EU, 2010), the Code for Sustainable Homes (CSH) assessment, and a series of other regulations aiming to improve the energy performance of houses and reduce their carbon emissions.

Despite this, many low carbon solutions are untested, creating a gap between 'expected' (modelled) and 'in-use' (measured or actual) energy performance. The result is that even new low carbon housing is using up to five times the energy predicted by models (Monahan and Gemmell, 2011; Thompson and Bootland, 2011). Although research has revealed that the physical building characteristics, performance of systems and occupant behaviour all play a significant role in determining actual energy use in buildings (Sharpe and Shearer, 2013; Gupta et al., 2013, Huebner et al., 2015; Jones and Lomas 2015; Gram-Hanssen, 
2010), the reasons for the gap between predicted and actual performance are not precisely understood. Concern is also growing in the UK that this performance gap found in typical mainstream home production has the potential to undermine zero carbon housing policy and carry considerable commercial risk for the wider industrial sector (Zero Carbon Hub, 2013). Evaluating the actual building performance of housing, taking account also of the relationship with user behaviour, can help establish some of the reasons for this gap and help to bridge it by suggesting design improvements related to these (Stevenson and Rijal, 2010; Zero carbon Hub, 2013, Ridley et al., 2014).

Furthermore, new housing in the UK is experiencing rapidly changing standards, especially in the social housing sector (which represented 25\% of all new homes in 2013/14 (DCLG, 2014)). Consequently, innovations have been made in materials, technologies and construction (Sharpe and Shearer, 2013). Given the risk of high energy costs associated with potential underperformance of such experiments and innovations, it could be argued that performance of social housing dwelling needs to be systematically evaluated in order to learn lessons and make the required changes to improve future designs. However little real feedback exists on how housing is performing during occupation, which makes it difficult to ascertain whether targets are being achieved in reality, whether the design, procurement, and management strategies are actually working and whether occupants are actually reducing their demands and expectations. The effectiveness of occupant feedback in clarifying why a technology does or does not work has been highlighted in several studies (Firth et al, 2008; Huebner et al., 2015).

An interdisciplinary approach has been suggested for identifying the unintended consequences derived from the implementation of new technologies and construction methods (Davies and Oreszczyn, 2012). In order to effectively map and address these issues, new approaches are needed that are able to capture the complexity of the built environment. Building Performance Evaluation (BPE) is widely acknowledged as an important mixed-method approach for gaining a deeper understanding of the environmental and energy performance of buildings. Despite this recognition, limited studies have been undertaken in the social housing sector for measuring actual fabric performance and reviewing the commissioning of services and systems (Wingfield et al, 2011; Gupta et al, 2013), as well as understanding the influence of occupant behaviour and interaction with technology.

Social housing is a means of providing accomodation that is affordable to people on low incomes. As such, residents are often more vulnerable both financially and physically. Therefore the promise of low energy bills in addition to lower than market-rate rent is very appealing. Since providers of social housing are responsible not only for the long term management and maintenance of the property, but also for their building's residents, it is important that they understand the risks involved in failing to deliver on the designed performance targets of a new dwelling (NEF, 2015): Occupants may be more at risk of illness due to indoor envrionmental conditions, and of fuel poverty - being faced with fuel bills that are unaffordable and unexpected given the 'low energy housing' status of their dwelling.

This study aims to considers all aspects of housing performance - building fabric, services and occupant related factors to systematically assess the reasons for the gap between modelled and measured energy use (and fuel costs) in social housing dwellings. Specifically the study investigates the actual energy use and environmental conditions of six case study 
social housing dwellings, located in three new low energy social housing developments in the UK, using the mixed-methods empirical approach of Building performance evaluation (BPE). Quantitative data on the performance of building fabric, services and indoor environment, are cross-related with qualitative data on communication of design intent, usability of control interfaces and occupant behaviour, to understand the reasons for the gap between modelled and actual energy use. Wider lessons and recommendations are drawn for the industry to reduce the gap between expected and actual performance of social housing dwellings.

\section{Evidence of housing performance evaluation}

Much of the research into the aforementioned performance gap has focussed on the building fabric performance. Indeed, evidence suggests that in a new-build dwelling, about $20-30 \%$ of the total heat loss arises from thermal bridging (Zero Carbon Hub, 2016) and up to $50 \%$ from air leakage (Energy Saving Trust, 2009). The majority of international studies (outlined in Table 1) found that test dwellings were falling short of their design targets in terms of airtightness and, consequently, with regards to energy performance.

Table 1 International studies and building fabric performance findings

\begin{tabular}{|c|c|c|}
\hline Study & No. of dwellings & Building Fabric Performance \\
\hline $\begin{array}{l}\text { Residential air-tightness } \\
\text { measurements, Greece } \\
\text { (A. Sfakianaki et al., 2008) }\end{array}$ & 20 & $\begin{array}{l}\text { Air changes/hour varied from } 0.6 \text { to } 7.0 \mathrm{ACH} \text { (at } 50 \mathrm{~Pa} \text { ). } \\
\text { Linear relationships between total length of window frame } \\
\text { and air tightness. }\end{array}$ \\
\hline $\begin{array}{l}\text { Contribution of windows and } \\
\text { shutters on space heating in } \\
\text { Portugal (Almeida et.al., } \\
\text { 2017) }\end{array}$ & 23 & $\begin{array}{l}\text { Windows contributed by } 15 \% \text { and roller shutters by by } \\
44 \% \text { to the rooms' permeability. }\end{array}$ \\
\hline $\begin{array}{l}\text { Dwelling airtightness } \\
\text { evaluation in Ireland } \\
\text { (Sinnott, 2016) }\end{array}$ & 9 & $\begin{array}{l}\text { Semi-detached social houses had measured and } \\
\text { modelled airtightness differing by up to } 89 \% \text {. }\end{array}$ \\
\hline $\begin{array}{l}\text { Air tightness in new } \\
\text { lightweight houses in } \\
\text { Estonia (Kalamees, 2007) }\end{array}$ & 32 & $\begin{array}{l}\text { Field measurements found a mean air leakage rate of } \\
4.2 \mathrm{~m}^{3} / \mathrm{h} / \mathrm{m}^{2} @ 50 \mathrm{~Pa} \text {, highlighting the quality of } \\
\text { workmanship as key to airtightness. }\end{array}$ \\
\hline $\begin{array}{l}\text { Airtightness of residential } \\
\text { buildings in Finland (Vinha } \\
\text { et al., 2015) }\end{array}$ & 226 & Workmanship identified as a key contributor to airtightness \\
\hline $\begin{array}{l}\text { Relationships between } \\
\text { building characteristics and } \\
\text { airtightness of Dutch } \\
\text { dwellings (Bramiana et al., } \\
\text { 2016) }\end{array}$ & $\begin{array}{l}\text { Data gathered from } \\
\text { several } \\
\text { organisations }\end{array}$ & $\begin{array}{l}\text { Air leakage paths identified included junctions and joints, } \\
\text { openings, service penetrations and fittings }\end{array}$ \\
\hline $\begin{array}{l}\text { Building leakage, infiltration, } \\
\text { and energy performance } \\
\text { analyses for Finnish } \\
\text { detached houses (Jokisalo } \\
\text { et al., 2009) }\end{array}$ & 170 & $\begin{array}{l}\text { An almost linear relationship between average infiltration } \\
\text { rate and heating energy use with the building leakage } \\
\text { rate. } 15-30 \% \text { of the space heating energy associated with } \\
\text { infiltration. }\end{array}$ \\
\hline $\begin{array}{l}\text { Air-tightness and its } \\
\text { Influencing factors on } \\
\text { airtightness inpost-2006 } \\
\text { new-build dwellings (UK) } \\
\text { (Pan, 2010) }\end{array}$ & 287 & $\begin{array}{l}\text { Critical influencing factors for airtightness include } \\
\text { management, build method and dwelling type. Dwelling } \\
\text { type and build method had a two-way interaction, } \\
\text { indicating an interactive rather than synchronous } \\
\text { relationship. Precast concrete builds were significantly } \\
\text { more airtight than masonry and reinforced concrete builds. }\end{array}$ \\
\hline
\end{tabular}


A sample of BPE studies in the UK are shown in Table 2, measuring the building fabric and energy performance of dwellings covering both social housing and private dwellings. The meta-analysis of BPE data of 83 social housing dwellings by NEF (2015) revealed that air tightness of $46 \%$ of the BPE test dwellings was below the design intent. Of the 14 dwellings in the AIMC4 programme, five used more (up to 196\% more) energy than the regulated energy usage shown in Standard Assessment Procedure (SAP) i (Gaze, 2014b). The largescale study at Stamford Brook found the effective U-values to be double the designed values for external walls of retrofitted dwellings and nearly three times greater for floors and ceilings (Wingfield et al., 2008). Passivhaus dwellings are not exempt from these deviations from design targets. However, the gap is much lower and often negligible, with discrepancies of the order of $0.01-0.06 \mathrm{~W} / \mathrm{m}^{2} \mathrm{~K}$ (Good Homes Alliance, 2014; Johnston et al., 2016; Guerra-Santin et al., 2013). A few studies have also shown that discrepancies that arise during the building process (design, modelling, buildability, materials, build quality, systems integration), as well as commissioning, handover and operation, can contribute to the performance gap in new dwellings (Gaze, 2014a; Wingfield, et al., 2011; Wingfield, et al., 2008).

Table 2 Domestic BPE studies and energy performance findings

\begin{tabular}{|c|c|c|}
\hline BPE programme & $\begin{array}{l}\text { Number of test } \\
\text { dwellings }\end{array}$ & Building fabric/energy Performance \\
\hline $\begin{array}{l}\text { National Energy Foundation } \\
\text { insights from social housing } \\
\text { projects (Seguro 2015) }\end{array}$ & 83 & $\begin{array}{l}\text { Air tightness of } 46 \% \text { of the test dwellings was below the } \\
\text { design intent. As-built external wall U-value of } 0.220 \mathrm{Wm}^{2} \mathrm{~K} \\
\text { exceeded the average design U-value of } 0.164 \mathrm{Wm}^{2} \mathrm{~K} \text {, with } \\
9 \text { properties failing to meet Building Regulations. }\end{array}$ \\
\hline $\begin{array}{l}\text { Innovate UK BPE (Palmer, } \\
\text { et al., 2016) }\end{array}$ & 350 (44 studies) & Emissions 2-3 times higher than design estimates. \\
\hline AIMC4 (Gaze, 2014b) & 17 (14 studied) & $\begin{array}{l}6 \text { dwellings lower than estimated SAP; eight higher actual } \\
\text { energy consumption than estimated SAP }\end{array}$ \\
\hline $\begin{array}{l}\text { Stamford Brook (Partners in } \\
\text { Innovation) (Wingfield et al., } \\
\text { 2008) }\end{array}$ & $\sim 700$ & Modelled lower than actual performance \\
\hline $\begin{array}{l}\text { Elm Tree Mews (Wingfield, } \\
\text { et al., 2011) }\end{array}$ & 4 houses $\& 2$ flats & Modelled heating input $\sim 2500 \mathrm{kWh}$ lower than actual \\
\hline $\begin{array}{l}\text { Good Homes Alliance } \\
\text { Monitoring Programme } \\
\text { (Medina et al., 2014) }\end{array}$ & 4 & $\begin{array}{l}\text { At One Brighton, while the monitored flat did not achieve } \\
\text { the electricity target set, over the entire development, } \\
\text { average electricity consumption did better the design target } \\
\text { of } 45 \mathrm{kWh} / \mathrm{m}^{2} / \text { annum. The heat demand target was also } \\
\text { achieved in the flat and across the site. }\end{array}$ \\
\hline $\begin{array}{l}\text { Low Energy Buildings } \\
\text { Database } \\
\text { (lowenergybuildings.org.uk/) }\end{array}$ & $\begin{array}{l}89 \text { new build } \\
\text { domestic }\end{array}$ & $\begin{array}{l}\text { Only estimated \& measured data available for three } \\
\text { dwellings; all below estimated target. }\end{array}$ \\
\hline
\end{tabular}

* 18 dwellings at St Nicholas Court (Partners in Innovation) also evaluated; however, measured in-use energy consumption is not available (R Lowe, Bell, \& Roberts, 2003).

A comprehensive review of the evidence of the gap between designed and as-built energy performance of new homes (excluding occupant related factors) was conducted by the Zero Carbon Hub (2014). Fifteen issues were identified as priority for action and generally related to construction and commissioning phases. Seventeen further issues were identified as priority for research and generally related to the detailed design and verification and testing stages. Three themes were also identified as significant barriers to improving the performance gap: knowledge and skills, responsibility, and communication. These themes hint at the role of the occupant in contributing to the energy performance gap. 
As evident from the review of literature, the majority of empirical studies investigating performance gap in new housing have tended to focus mainly on as-built performance by assessing issues with design, building fabric or services. There appears to be paucity of empirical studies that have systematically measured occupant understanding of the dwelling, their comfort and behaviour, which can sometimes have a positive (e.g. wearing warmer clothes to offset the need for heating) or negative (leaving windows open when the heating is on) influence on energy performance.

\section{Methodology}

Building performance evaluation (BPE) is the process of evaluating the performance of a building through a systematic collection and analysis of qualitative and quantitative data related to energy performance, environmental conditions and occupant feedback. BPE involves feedback and evaluation reviews at every phase of the building delivery from strategic planning to occupancy, adaptive reuse and recycling (Preiser and Visher, 2005). In recent years, several methods have been developed to capture co-incident data from monitoring and occupants (Stevenson and Rijal, 2010). This paper presents data and findings from three BPE (one Phase I and two Phase II projects) studies undertaken by the authors. These studies are part of the UK Government's (Innovate UK, formerly Technology Strategy Board) £8 million 4-year national research programme on BPE (TSB, 2012) to evaluate and assess the post-construction and in-use performance of both domestic and non-domestic buildings. The programme mandated a prescribed protocol for evaluation and reporting, to maintain consistency and comparability in benchmarking and analysis. Studies include Phase I projects, which undertook post-construction testing and early occupancy, and Phase II studies, which additionally undertook monitoring of energy and environmental conditions for a 24-month period.

In this study, the actual energy and environmental performance of six low energy case study social housing dwellings were assessed through concurrent data on energy use and in-situ environmental conditions including air quality (temperature, relative humidity $(\mathrm{RH})$ and $\mathrm{CO}_{2}$ levels) as well as opening and closing of doors and windows. These data were collected between January 2013 and December 2013 (12 months) at five minute intervals using Radiotech remote monitoring sensors and transmitted wirelessly from a RT:Wi5 data-hub. This physical data were cross related with qualitative data gathered through occupant satisfaction surveys and interviews, supplemented by occupant self-completion activity logging and thermal comfort diaries across different seasons. This included occupants' feedback on their washing and showering regimes and thermostat settings. Building fabric performance was tested using diagnostic field tests (air-permeability testsii, in-situ thermal transmittance (U-value) tests ${ }^{\text {iii }}$, and infrared thermographyiv) along with a review of the installation and commissioning of services and systems. The communication of design intent to residents was evaluated by observing the handover process and assessing the home user guides. Usability was assessed through a detailed qualitative review of control interfaces that occupants interact with.

\section{Overview of case studies}

The six case study dwellings are part of three exemplar social housing developments (A, B and C) located in South-East England. All developments were completed between 2011 and 2012: Case A has been occupied since March 2011, Case B since August 2012 and Case C 
since March 2012. The six case studies (two per development - A1, A2, B1, B2, C1 and C2) were selected to represent a variety of built forms and construction systems. The case study houses are two and three storey mid-terrace, end-terrace and detached houses of two, three and five bedrooms, located in residential areas. The size of the properties varies; the smallest being $94 \mathrm{~m}^{2}$ and the largest being $146 \mathrm{~m}^{2}$. The layout of the houses is similar (with the living areas on the ground floor and sleeping areas on the upper floors), with the exception that Case $A$ houses have an open plan layout on the ground floor. Cases $A 1, A 2$, $\mathrm{C} 1$ and $\mathrm{C} 2$ were monitored for a period of two years and Cases B1 and B2 were monitored for a period of one year. Table 3 presents an overview of the design specifications and construction details of the case studies, while Table 4 shows their occupancy characteristics.

Table 3 Design specifications and construction details of case study dwellings

\begin{tabular}{|c|c|c|c|}
\hline & Development A & Development B & Development C \\
\hline Developer & \multicolumn{3}{|c|}{ Social housing / Local authority } \\
\hline Tenure & \multicolumn{3}{|l|}{ Affordable housing rented } \\
\hline Completion date & March 2011 & August 2012 & March 2012 \\
\hline Area $\left(m^{2}\right)$ & 94 & 94 & 88 \\
\hline Typology & Two bed, mid-terrace & Two bed, mid-terrace & $\begin{array}{l}\text { Three bed, end- } \\
\text { terrace }\end{array}$ \\
\hline Floors & 2 & 2 & 2 \\
\hline Construction type & $\begin{array}{l}\text { Timber frame with cast } \\
\text { hempcrete }\end{array}$ & $\begin{array}{l}\text { Steel frame with pre- } \\
\text { insulated panels }\end{array}$ & $\begin{array}{l}\text { Timber frame and } \\
\text { brick }\end{array}$ \\
\hline Target design rating & CSH Level 5 & CSH Level 4 & CSH Level 4 \\
\hline $\begin{array}{l}\text { Main construction } \\
\text { elements (as } \\
\text { designed) } \\
\text { U-values } \mathrm{W} / \mathrm{m}^{2} \mathrm{~K}\end{array}$ & $\begin{array}{l}\text { Walls U-value: } 0.18 \\
\text { Roof U-value } 0.15 \\
\text { Floor U-value } 0.2 \\
\text { Windows: double } \\
\text { glazing, U-value } 1.4\end{array}$ & $\begin{array}{l}\text { Walls U-value: } 0.15 \\
\text { Roof U-value: } 0.15 \\
\text { Floor U-value: } 0.15 \\
\text { Windows: triple } \\
\text { glazing, U-value } \leq 1.2\end{array}$ & $\begin{array}{l}\text { Walls U-value } 0.21 \\
\text { Roof U-value } 0.13 \\
\text { Floor U-value } 0.25 \\
\text { Windows: double } \\
\text { glazing, U-value } 1.3\end{array}$ \\
\hline $\begin{array}{l}\text { Space heating and } \\
\text { hot water system }\end{array}$ & $\begin{array}{l}\text { Exhaust Air Heat Pump } \\
\text { (EAHP), underfloor } \\
\text { heating and solar } \\
\text { collectors }\end{array}$ & $\begin{array}{l}\text { Air Source Heat Pump } \\
\text { (ASHP), underfloor } \\
\text { heating coils, } \\
\text { immersion heater back } \\
\text { up }\end{array}$ & $\begin{array}{l}\text { Gas condensing } \\
\text { boiler with radiators }\end{array}$ \\
\hline $\begin{array}{l}\text { Target air } \\
\text { permeability } \\
\left(\mathrm{m}^{3} / \mathrm{hm}^{2} @ 50 \mathrm{~Pa}\right)\end{array}$ & 2 & 3 & 3 \\
\hline Ventilation strategy & $\begin{array}{l}\text { Whole house } \\
\text { MVHR through EAHP }\end{array}$ & Whole house MVHR & Whole house MVHR \\
\hline Renewables & 4kWpk Photovoltaics & 1.5kWpk Photovoltaics & $\begin{array}{l}1.65 \mathrm{kWp} \& 1.88 \mathrm{kWp} \\
\text { Photovoltaics }\end{array}$ \\
\hline
\end{tabular}

The Code for Sustainable Homes (CSH) iii target ratings are given on a scale of 1 to 6 , where 6 represents the highest standard. Development A was designed for CSH Level 5 (equivalent to a $100 \%$ improvement in $\mathrm{CO}_{2}$ Dwelling Emission Rate over Target Emission Rate) and Developments B and C were designed for CSH Level 4 (equivalent to at least a $25 \%$ improvement in $\mathrm{CO}_{2}$ Dwelling Emission Rate over Target Emission Rate). Different types of 
construction were used in the three developments ranging from hempcrete in Development $A$ to light-weight steel frame construction with pre-insulated panels in Development $B$ and more traditional timber frame with brick in Development C. Additionally, each of the developments features a different heating system; from Exhaust Air Heat Pumps (EAHP) in Development A to Air Source Heat Pumps (ASHP) in Development B and gas boilers in Development C. Designed for air permeability of $2-3 \mathrm{~m}^{3} / \mathrm{m}^{2} \mathrm{~h}$, all case study dwellings have whole house mechanical ventilation with heat recovery systems (MVHR) along with windows that can be manually opened and closed. All six dwellings also have solar photovoltaic systems to provide electricity, and all but dwellings $\mathrm{C} 1$ and $\mathrm{C} 2$ are electrically heated. All of the six case study houses are occupied by families with children (Table 4). The number of occupants is high, ranging from 4 people ( 2 adults and 2 children below the age of 12 in Cases A1, A2 and B1), 5 people (4 adults and 1 baby in Case B2, 2 adults and 3 children in Case C1) and 6 people ( 1 adult and 5 children below the age of 16 in Case C2). Cases A1, A2 and B2 are occupied 24 hours/7 days a week, and Cases B1, C1 and C2 are occupied 17-19 hours during weekdays and 24 hours during weekends.

Table 1 Occupancy characteristics of case study dwellings

\begin{tabular}{|c|c|c|c|c|c|c|}
\hline & \multicolumn{2}{|c|}{ Development A } & \multicolumn{2}{|c|}{ Development B } & \multicolumn{2}{|c|}{ Development C } \\
\hline $\begin{array}{l}\text { No of case study } \\
\text { houses }\end{array}$ & \multicolumn{2}{|l|}{2} & \multicolumn{2}{|l|}{2} & \multicolumn{2}{|l|}{2} \\
\hline $\begin{array}{l}\text { Case study } \\
\text { reference }\end{array}$ & Case A1 & Case A2 & Case B1 & Case B2 & Case C1 & Case C2 \\
\hline $\begin{array}{l}\text { Occupancy } \\
\text { patterns }\end{array}$ & \multicolumn{2}{|c|}{$\begin{array}{l}\text { Weekdays: } 24 \mathrm{~h} \\
\text { Weekend: } 24 \mathrm{~h}\end{array}$} & $\begin{array}{l}\text { Weekdays: } \\
\text { 15:00-8:00 } \\
\text { Weekend: } \\
\text { 24h }\end{array}$ & $\begin{array}{l}\text { Weekdays: } \\
\text { 24h } \\
\text { Weekend: } \\
\text { 24h }\end{array}$ & \multicolumn{2}{|c|}{$\begin{array}{l}\text { Weekdays: } \\
\text { 13:00-8:00 } \\
\text { Weekend: } 24 \mathrm{~h}\end{array}$} \\
\hline Occupants & $\begin{array}{l}2 \text { adults, } \\
2 \text { children }\end{array}$ & $\begin{array}{l}2 \text { adults, } \\
2 \text { children }\end{array}$ & $\begin{array}{l}2 \text { adults, } \\
2 \text { children }\end{array}$ & $\begin{array}{l}4 \text { adults, } \\
1 \text { baby }\end{array}$ & $\begin{array}{l}2 \text { adults, } \\
3 \text { children }\end{array}$ & $\begin{array}{l}1 \text { adult, } \\
5 \text { children }\end{array}$ \\
\hline
\end{tabular}

\section{Results}

\section{Building fabric performance}

With over $60 \%$ of domestic energy use coming from space heating (Department of Energy and Climate Change, 2013), the quality of the building fabric has a major effect on dwelling energy use. The building fabric performance of the case study dwellings was tested using diagnostic field tests that included: air permeability tests, in-situ thermal transmittance (Uvalue) tests and infrared thermography. All tests were carried out after occupant move-in and during the monitoring period of 2013-2014.

Overall wall insulation levels were found to be as-designed in all cases, even though thermographic images revealed some heat loss through window and door frames and thermal bridges across ceiling beams and thresholds. However, air permeability tests showed that all six dwellings missed their design air permeability target of 2-3 m $3 / \mathrm{m}^{2} \mathrm{~h}$ with most cases being twice as high as designed (Figure 1). All case study houses failed to comply with the best practice air permeability rate $\left(5 \mathrm{~m}^{3} / \mathrm{m}^{2} . \mathrm{h}\right)$ recommended by CIBSE TM23 (CIBSE, 2000). In fact, Case A2 (15 m³.h.m² @ 50 Pa) did not even meet the 2010 Building Regulation standard $\left(10 \mathrm{~m}^{3} / \mathrm{m}^{2} . \mathrm{h}\right)$, demonstrating inadequate enforcement of compliance and verification procedures. These values are similar to those measured after completion and before occupancy, indicating construction and workmanship issues rather than occupant intervention. In Case A1 in particular, the high air permeability rate is due to a 
large breach in the air-permeability membrane between the EAHP cupboard and the roof space. It is interesting to note that none of the case studies achieved actual air permeability levels of $5 \mathrm{~m}^{3} / \mathrm{m}^{2} \mathrm{~h}$ at which MVHR systems are recommended (EST, 2010).

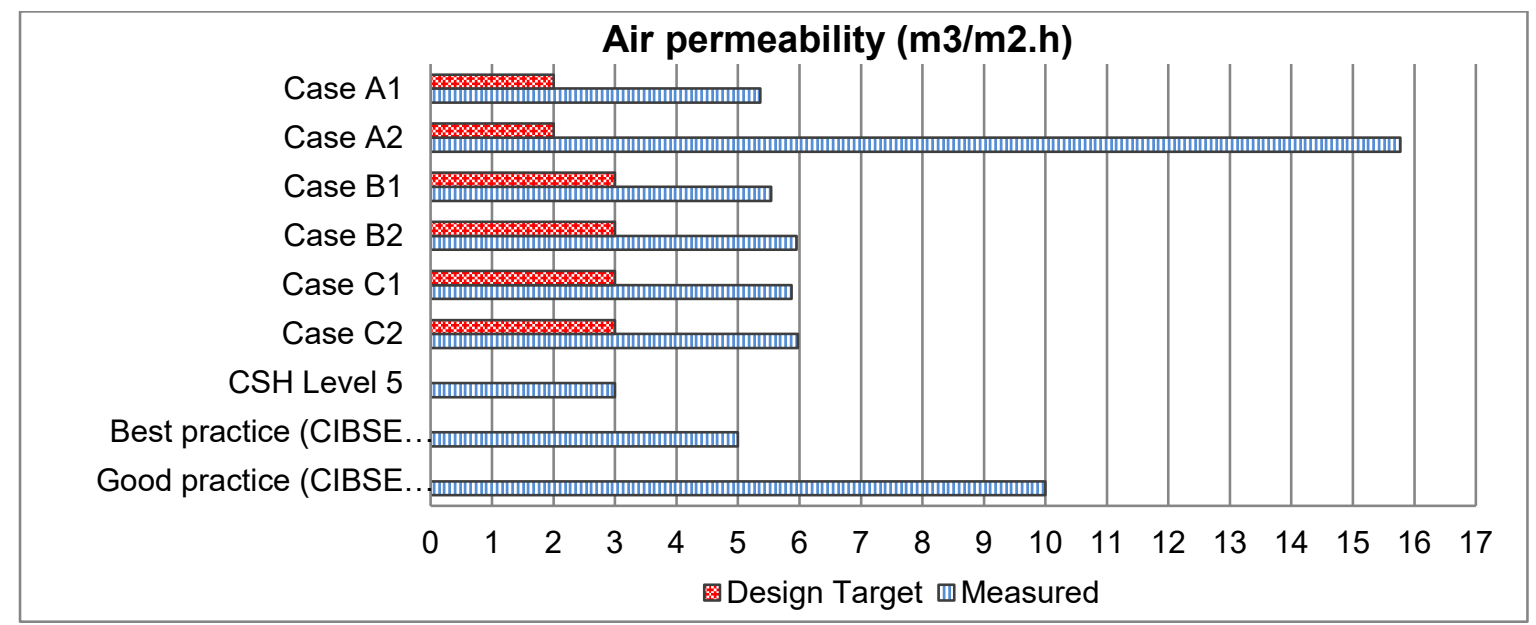

Figure 1 Comparison of measured and design air permeability.

\section{Heating and ventilation systems}

The design, installation and commissioning of heating and ventilation systems was examined to ensure the systems are capable of creating the required environmental conditions and whether the operational strategy was likely to deliver the desired performance and comfort for the occupants. Several issues were revealed in the installation and commissioning of heat pumps in developments $A$ and $B$, and mechanical ventilation systems across all three developments. Table 5 summarises the common issues across the three developments.

Table 5 Common issues highlighted by review of systems installation and commissioning

\begin{tabular}{|l|c|c|c|}
\hline & $\begin{array}{c}\text { Development } \\
\text { A }\end{array}$ & $\begin{array}{c}\text { Development } \\
\text { B }\end{array}$ & $\begin{array}{c}\text { Development } \\
\text { C }\end{array}$ \\
\hline $\begin{array}{l}\text { MVHR imbalance between supply and extract air } \\
\text { flow }\end{array}$ & $\mathbf{x}$ & $\mathbf{x}$ & $\mathbf{x}$ \\
\hline MVHR unit located in loft inaccessible & & $\mathbf{x}$ & $\mathbf{x}$ \\
\hline MVHR terminals not locked in fixed positions & $\mathbf{x}$ & $\mathbf{x}$ & $\mathbf{x}$ \\
\hline $\begin{array}{l}\text { MVHR terminals closed by occupants due to cold } \\
\text { air }\end{array}$ & & $\mathbf{x}$ & $\mathbf{x}$ \\
\hline Several MVHR system breakdowns & $\mathbf{x}$ & $\mathbf{x}$ & $\mathbf{x}$ \\
\hline Poorly commissioned heating controls & $\mathbf{x}$ & $\mathbf{x}$ & \\
\hline
\end{tabular}

MVHR systems were chosen in all the three developments to achieve code compliance at the design stage. The developers (housing association or the local authority) reported that they had little knowledge and experience in the design, specification, installation, commissioning and maintenance of MVHR systems. In addition, the sub-contractors failed to install and commission the MVHR systems according to the specifications, as revealed by the commissioning review undertaken during the study. Poor maintenance further aggravated the problems, as the commissioning errors were not addressed effectively. These issues led to imbalance between supply and extract air up to $53 \%$ in Case A1 and $28 \%$ in Case C2; frequent breakdowns (Cases B1, B2), noise (Case C1) and cold draughts (Case B1). The MVHR supply and extract terminals in all cases were not locked in fixed 
positions, allowing the occupants to adjust them at will, resulting in insufficient fresh air supply, adding further to system imbalance and affecting indoor air quality. System imbalances can also lead to increased heat loss and energy use, as well as increased system resistance that leads to noise (Price and Brown, 2012). Cold draughts due to system imbalance led occupants to completely switch off the MVHR system in Cases B1 and C1 and to close the supply terminals in Case $\mathrm{C} 2$, potentially compromising the indoor air quality.

The performance of the heating systems did not always meet the specification standards. In Cases A1 and A2 the Coefficient of Performance (COP) of the Exhaust Air Heat Pumps (EAHP, which provides space heating and hot water) installed was measured as 1.4, while the design specification average COP was 2.6. Findings from the Energy Savings Trust field trials reveal how commissioning and control issues can affect the performance of heat pumps (EST, 2013).

In addition to this, the connection of heating controls with room thermostats was also found to be problematic in most houses. In Development $A$, a commissioning check before the move-in revealed that zone thermostats were not properly wired to the master thermostat, an issue that was resolved as part of the BPE study. In Development B, some of the wireless room thermostats had not been connected to the heating systems resulting in the heating being constantly on, even during summer. This issue made occupants in Cases B1 and B2 feel a perceived lack of control over heating and made them sceptical towards the heat pump and other technologies used in the houses. The commissioning problem was discovered during the study several months after the move-in following occupant complaints of overheating. Due to the system underperformance and perceived lack of control, occupants in Case B1 turned off the heating system completely during the day, in an attempt to save energy, without realising the unintended consequences this would have on the energy and environmental performance of the house. In contrast, Case B2's occupants had not realised the system failure and experienced very high temperatures over a prolonged period of time during summer.

\section{Occupant related factors}

\section{Occupant understanding: communication of design intent}

In order to identify the influence of occupant behaviour on housing performance, it is essential to capture the actual process by which the occupants develop their own understanding of how to use the home (Stevenson and Rijal, 2010). The formal introduction to the home is the first critical interface between the inhabitant (occupant) and their interaction with the building. The handover process (home introduction and training) and guidance (home user guide, technical manuals) that occupants receive before and after moving into their new home was carefully evaluated in terms of clarity, communication and user engagement. The findings are triangulated with the occupants' answers to interview questions about the effectiveness of the handover process, to gain deeper insight into occupants' understanding of the systems and to establish whether the documentation that occupants received was sufficient in communicating the design intent and operation of the new home without being overly technical or confusing. To achieve this, the housing association's (HA's) occupant handover process, which took place before occupants moved in the properties, was directly observed (providing rich feedback that was relatively quick to capture), with a member of the evaluation team shadowing a typical user introduction to the 
equipment and functioning of the home by HA's representative. Table 6, below, summarises the common issues that were highlighted by the handover observation and review of guidance offered to the occupants. Most of these issues were prevalent across the three developments.

Table 6 Common emerging issues highlighted by the review of handover and user guidance

\begin{tabular}{|l|c|c|c|}
\hline & $\begin{array}{c}\text { Development } \\
\text { A }\end{array}$ & $\begin{array}{c}\text { Development } \\
\text { B }\end{array}$ & $\begin{array}{c}\text { Development } \\
\text { C }\end{array}$ \\
\hline No phased approach followed during handover & $\mathbf{x}$ \\
\hline $\begin{array}{l}\text { Handover would have benefited by follow-up } \\
\text { sessions at least in summer and winter }\end{array}$ & $\mathbf{x}$ & $\mathbf{x}$ \\
\hline $\begin{array}{l}\text { Handover/induction/training did not let occupants try } \\
\text { out systems and controls }\end{array}$ & $\mathbf{x}$ & $\mathbf{x}$ \\
\hline $\begin{array}{l}\text { Home user guide should be more simple and clear } \\
\text { technologies installed in the house }\end{array}$ & $\mathbf{x}$ & $\mathbf{x}$ & \\
\hline $\begin{array}{l}\text { Home user guide could be shorter and more } \\
\text { straightforward }\end{array}$ & $\mathbf{x}$ & $\mathbf{x}$ & $\mathbf{x}$ \\
\hline
\end{tabular}

Since the housing associations (as social landlords) have experience of managing a large stock of tenanted properties, they were more successful in organising and delivering comprehensive and engaging handover, training sessions and guidance, when compared to the Local authority owned Development $C$. Although in developments $A$ and $B$ the handover demonstrations were phased (before move-in, one month after move-in, and three months after move-in) and clear, the occupants were not given the opportunity to try the various systems and control features for themselves which might have aided their initial understanding of how to use them. In Development $C$, there was no phased approach to handover, with occupants expected to comprehend a large amount of technical information (related to exhaust air heat pumps and mechanical ventilation) on the day of the handover itself. The review of home user guides revealed that they were usually lengthy documents containing extensive technical details from manufacturers' manuals which were often poorly illustrated, and failed to provide simple and clear guidelines on how to make the best use of heating and ventilation systems (at least on a seasonal basis - summer and winter modes). This was partly the reason why occupants across all the three developments seemed to have failed to fully understand and retain the purpose and operation of the heating (especially heat pumps and underfloor heating) and mechanical ventilation systems, or seemed to have forgotten the information that was provided to them initially (Gupta and Kapsali, 2014). Findings also suggest that not all occupants understood the training and guidance provided in the same way, suggesting that attention to any kind of training or guidance is also a matter of personal interest, as well as technical ability and age (BSRIA, 2014; Gupta and Kapsali, 2014).

\section{Usability of control interfaces}

Control interfaces were the meeting point between users and building technology or fabric. The six-point criteria developed by Buildings Controls Industry Association (BCIA) were used to visually rate the performance and usability of control interfaces (Bordass et al, 2007) of heating, ventilation and lighting systems, as well as touch-points of the building fabric (window controls). These criteria include clarity of purpose, intuitive switching, usefulness of labelling and annotation, ease of use, indication of system response, degree of fine control 
as well as accessibility. Such investigations into the relationship between the design and usability of controls give an indication of their effect on occupant control and housing performance (Topouzi, 2013). Table 7 below summarises the overall key issues that emerged as a result of the review and rating of control interfaces across the three developments.

Critical controls such as thermostats (for setting indoor temperatures for heating systems) were found to have poor ease of use and indication of system response in both Developments A and B, albeit for different reasons. In Development B the designer's intention to provide occupants with good levels of control resulted in an over-engineered solution of six to eight room thermostats and one master thermostat per house, as well as excessive thermal zones that confused the occupants and could not be commissioned properly. In Development A, temperatures were not graphically indicated on the thermostat dials that only featured an arbitrary scale and showed no indication of system response. In the absence of clear annotation and numbering the users had to experiment to figure out which setting would offer comfortable temperatures. Such issues led to poor ease of use and lack of occupant understanding in both cases. This in turn affected occupants' ability to manage their comfort and resulted in increased heating energy use. Furthermore, controls and systems that are kept 'out of sight' were ignored by the occupants leading to poor maintenance (filter change) or even disuse.

Table 7 Common issues highlighted by review of control interfaces

\begin{tabular}{|l|c|c|c|}
\hline & $\begin{array}{c}\text { Development } \\
\text { A }\end{array}$ & $\begin{array}{c}\text { Development } \\
\text { B }\end{array}$ & $\begin{array}{c}\text { Development } \\
\text { C }\end{array}$ \\
\hline Conflicting control strategies & $\mathbf{x}$ & $\mathbf{x}$ & \\
\hline $\begin{array}{l}\text { Oversimplified control interfaces } \\
\text { (no indication of system response, no labelling) }\end{array}$ & $\mathbf{x}$ & \\
\hline Overcomplicated heating controls and zoning & & $\mathbf{x}$ & \\
\hline No indication of MVHR failure or maintenance & $\mathbf{x}$ & $\mathbf{x}$ & $\mathbf{x}$ \\
\hline MVHR unit inaccessible, located in loft & & $\mathbf{x}$ & $\mathbf{x}$ \\
\hline Windows and doors offer good fine control & & $\mathbf{x}$ & $\mathbf{x}$ \\
\hline
\end{tabular}

Apart from issues with heating controls, provision of usable and well-located controls for the mechanical ventilation (MVHR) system was also a common issue for all case studies. In Cases $A 1$ and $A 2$ boost buttons were hidden in cupboards on the first floor but occupants in both houses were not aware of it. Occupants in Developments $B$ and $C$ were even unaware of the location of the MVHR units, which sat in the roof spaces that are narrow and difficult to access. As a result of this, the MVHR system in Case B2 had broken down without the occupants realising it. Furthermore, the position of the supply outlets of the MVHR system directly above the beds in Case B1 bedrooms caused great discomfort (due to cold draughts arising from system imbalance) to the occupants who decided to manually shut the supply terminals. Had this development been as airtight as originally specified, reducing the fresh-air supply could have put the occupants' health and well-being at risk. The findings related to MVHR system installation, location of outlet terminals and inaccessible controls were particularly concerning as the use of these systems is becoming wide-spread in new houses (Behar and Chiu, 2013). With such deficiencies in installation, commissioning and operation, the future take-up of these systems for their contribution to ventilation, occupant health and achieving energy reduction, may become questionable $(\mathrm{ZCH}, 2013$; Gupta and Kapsali, 2014). Such issues reveal the need for establishing a clear and integrated systems and 
controls strategy early on in the design process, as also suggested by Soft Landings (BSRIA, 2014).

\section{Occupant perceptions and experiences}

To gain deeper insights into how occupant behaviour influenced housing performance, direct verbal feedback was gathered on the perceptions and experiences of the occupants once they had lived in their homes for a while and had become familiar with them. This was done through self-completed occupant questionnaire surveys and a 45-minute, semi-structured interview-walkthrough. Occupant surveys were carried out in all three developments using the domestic version of standardised Building Use Studies (BUS 1 ) questionnaire which assesses occupants' reported levels of comfort and satisfaction with the dwellings design and internal conditions (summer and winter), and also evaluates the degree to which occupants perceive their needs are being met by the building. Completed BUS questionnaires were collected from eight houses in Development $A$ ( $60 \%$ response rate), sixteen houses in Development B ( 70\% response rate), and eight houses in Development C ( $80 \%$ response rate) giving an overall response rate of $70 \%$.

Following the occupant surveys, more detailed information on occupant views, satisfaction and concerns was gathered through semi-structured interviews and walkthroughs with the occupants of the six case study houses and triangulated with the findings from the BUS surveys. Table 8 summarizes the positive and negative occupant feedback relating to controls, comfort and satisfaction with space, that was collated from the BUS survey and occupant interview-walkthroughs. Most of the findings were consistent with the findings from the physical performance of the services and systems, as well as the review of handover and control interfaces.

Table 8 Issues revealed by occupant survey and qualitative interviews

\begin{tabular}{|l|c|c|c|} 
& $\begin{array}{c}\text { Development } \\
\text { A }\end{array}$ & $\begin{array}{c}\text { Development } \\
\text { B }\end{array}$ & $\begin{array}{c}\text { Development } \\
\text { C }\end{array}$ \\
\hline Positive feedback & $\mathbf{x}$ & $\mathbf{x}$ & $\mathbf{x}$ \\
\hline Satisfaction with space and layout & $\mathbf{x}$ & $\mathbf{x}$ & $\mathbf{x}$ \\
\hline Satisfaction with design and appearance & $\mathbf{x}$ & $\mathbf{x}$ \\
\hline Satisfaction with light levels (natural, artificial) & $\mathbf{x}$ & $\mathbf{x}$ & $\mathbf{x}$ \\
\hline Perceived overall internal temperatures good & & $\mathbf{x}$ & \\
\hline Negative feedback & $\mathbf{x}$ & $\mathbf{x}$ & $\mathbf{x}$ \\
\hline Poor control over heating system & $\mathbf{x}$ & $\mathbf{x}$ & $\mathbf{x}$ \\
\hline $\begin{array}{l}\text { Lack of understanding of operating heating } \\
\text { system }\end{array}$ & $\mathbf{x}$ & $\mathbf{x}$ & $\mathbf{x}$ \\
\hline Lack of knowledge about MVHR system & $\mathbf{x}$ & $\mathbf{x}$ & $\mathbf{x}$ \\
\hline Poor control over mechanical ventilation & & & \\
\hline Hot during summer & & \\
\hline Home User Guide considered complicated. & & \\
\hline Energy bills considered high & & \\
\hline
\end{tabular}

Occupants were fairly satisfied with the appearance, design, layout and space of the houses across all three case study developments. Most negative feedback revolved around the

1 The BUS methodology is an established way of benchmarking levels of occupant satisfaction within buildings using a structured questionnaire where respondents rate various aspects of performance on a scale of 1-7. 
operation and control of the heating and mechanical ventilation systems, with occupants in development B finding summer temperatures high, probably due to uncontrollable and excessive heating from the underfloor central heating system. Interviews with occupants revealed that control over heating was considered problematic in Developments A and B that feature air source heat pumps and underfloor heating, as these were unfamiliar technologies. The unfamiliarity was confounded by the lack of clear guidance in the Home User Guide. Occupants also appeared confused about the operation of the MVHR system, which they also perceived as expensive because it was 'always on', to the extent that they manually overrode it and ventilated their houses by opening the windows on a daily basis to tackle poor levels of indoor air quality, despite the heating being on.

\section{Energy use and fuel costs}

The effect of the performance of building fabric, services and systems, and occupant related factors was observed through the analysis of the monitoring data on gas and electricity use, for the period between January 2013 and December 2013. Comparison of actual annual energy use with 'as designed' Standard Assessment Procedure (SAP) calculations revealed that actual electricity and gas use was between 2 to 4 times higher than the SAP estimated energy use and actual $\mathrm{CO}_{2}$ emissions were between 4 to 12 times higher than calculations. These discrepancies were partly due to the fact that SAP did not cover all end uses of energy such as electricity used for appliances. To overcome this, SAP calculations were enhanced to include electricity for lighting and appliances and energy used for cooking, using an MS Excel worksheet provided by the Technology Strategy Board as part of their national Retrofit for the Future programme. As shown in Figure 2, annual energy use exceeded the extended SAP estimates by a factor of 2 in most cases and by a factor of 3 in Case C1, with actual emissions being 2 to 3 times higher than the extended SAP emissions estimate.

The key reasons leading to this performance gap were the underperformance of the fabric and systems (poor air tightness, inadequate commissioning of the heat pumps and poorly balanced MVHR system airflow), and also the unintended consequences related to lack of control, system misuse and occupant expectations, as explained in the previous sections. In fact, occupant expectations and lack of control led to excessive heating from the underfloor central heating system (Developments $A$ and $B$ ) and always on radiators and winter window opening patterns (Development $C$ ), all of which contributed to the poor energy performance. 

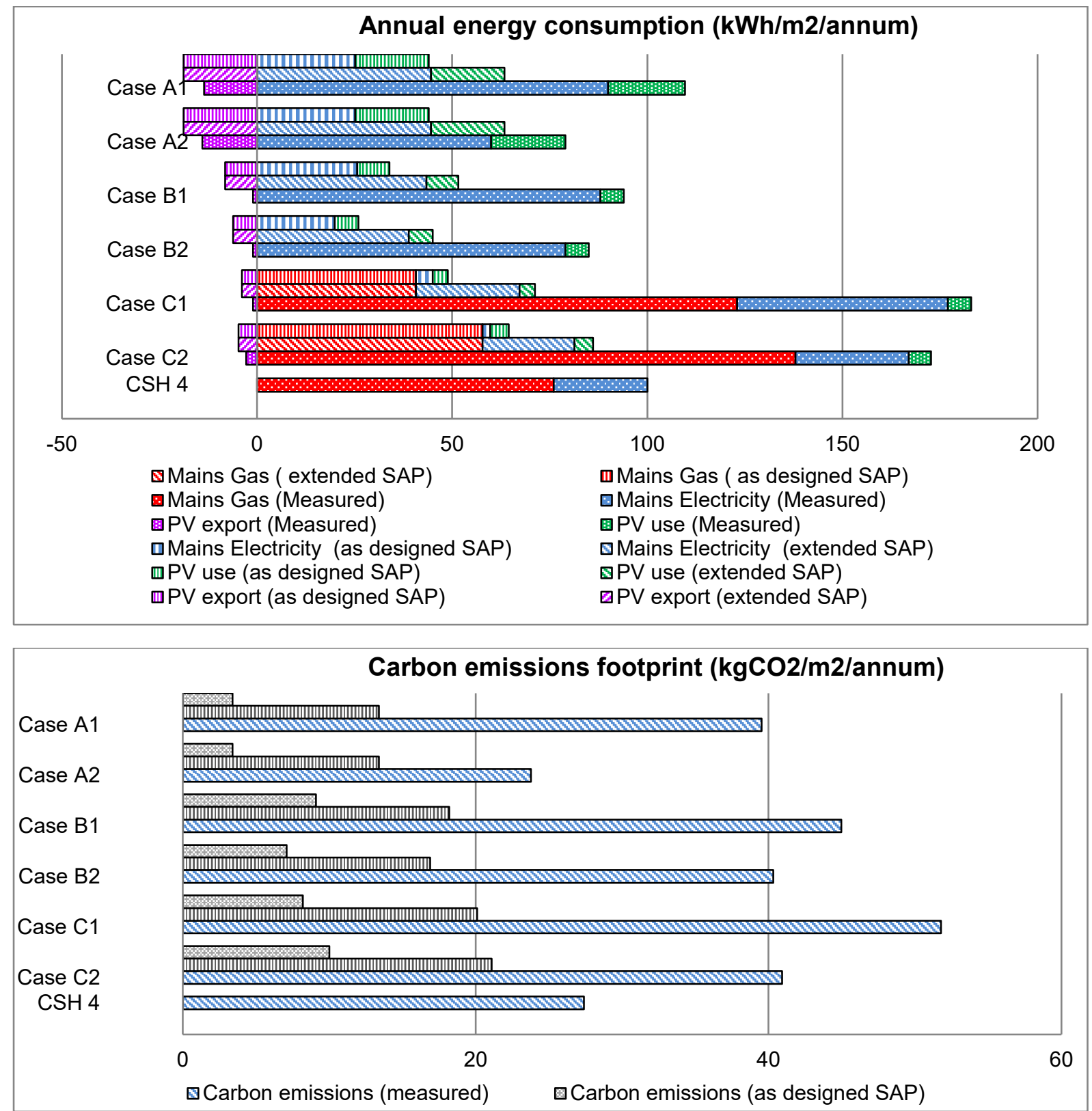

Figure 2 Comparison of actual annual energy consumption and $\mathrm{CO}_{2}$ emissions with SAP and Extended SAP model predictions across all cases (January 2013-December 2013). $\mathrm{CO}_{2}$ emission factors: Electricity $0.517 \mathrm{kgCO} / \mathrm{kWh}$, Gas $0.198 \mathrm{kgCO} / \mathrm{kWh}$.

Interesting findings emerged when cases were compared against each other. Case A1, although designed for CSH Level 5, consumed more electricity than Cases B1 and B2, which were designed for $\mathrm{CSH} 4$. This was partly due to the lower Coefficient of Performance (COP) of the exhaust air heat pumps (EAHPs) installed in Cases A1 and A2 measured as 1.4, compared with the COP of the ASHP in Cases B1 and B2 specified as 3.13. However, Cases $\mathrm{C} 1$ and $\mathrm{C} 2$ (with conventional gas central heating and MVHR systems) had the worst energy performance in the sample.

There was also significant variation in the energy performance of identical houses within the same development designed to the same standard and with similar occupancy patterns. For 
instance, occupants in Case A2, which had higher air permeability than A1, consumed 30 $\mathrm{kWh} / \mathrm{m}^{2}$ /annum less electricity than their neighbours in Case A1 (Figure 12), implying the direct effect of occupant behaviour and expectations on housing performance. Occupant feedback through surveys, in addition to on-site inspections, revealed that occupants in Case A2 kept their thermostat at $19{ }^{\circ} \mathrm{C}$ and were more energy conscious than their neighbours in $\mathrm{A} 1$ who kept the thermostat between $25-27^{\circ} \mathrm{C}$ and also did not understand the operation of the heating controls. This resulted in higher annual energy use and associated $\mathrm{CO}_{2}$ emissions in Case A1 by a factor of 1.4 when compared against Case A2. Also in Development $\mathrm{B}$, annual $\mathrm{CO}_{2}$ emissions and actual energy use in Case $\mathrm{B} 1$ were higher than those of Case B2 by a factor of 1.1, even though Case B2 was occupied by more adults and for longer hours. This was due to poor occupant understanding of the ASHP and underfloor heating. Although occupants of cases $\mathrm{C} 1$ and $\mathrm{C} 2$ preferred to set their thermostats as high as $30^{\circ} \mathrm{C}$ throughout the day, the annual gas use of Case $\mathrm{C} 2$ only slightly exceeded that of Case C1, since Case C2 occupants also habitually left the living room windows open throughout the day even during winter. However electricity use in Case $\mathrm{C} 1$ was higher than that of Case C2 due to the occupants' washing and showering regime, which was identified from the occupant's daily occupancy and activity logging sheets). Energy by end-uses is shown in Figure 3. The unregulated loads, including small power, cooking, refrigeration and wet appliances, account for $32 \%$ of total energy use in Case A1, 35\% in Case A2, $28 \%$ in Case $\mathrm{C} 1$ and $14 \%$ in Case $\mathrm{C} 2$, indicating the underestimation of the domestic energy demand through SP type models was one of the parameters leading to the performance gap. The discrepancies in energy use between case study houses indicated the effect of individual occupant behaviour and control.

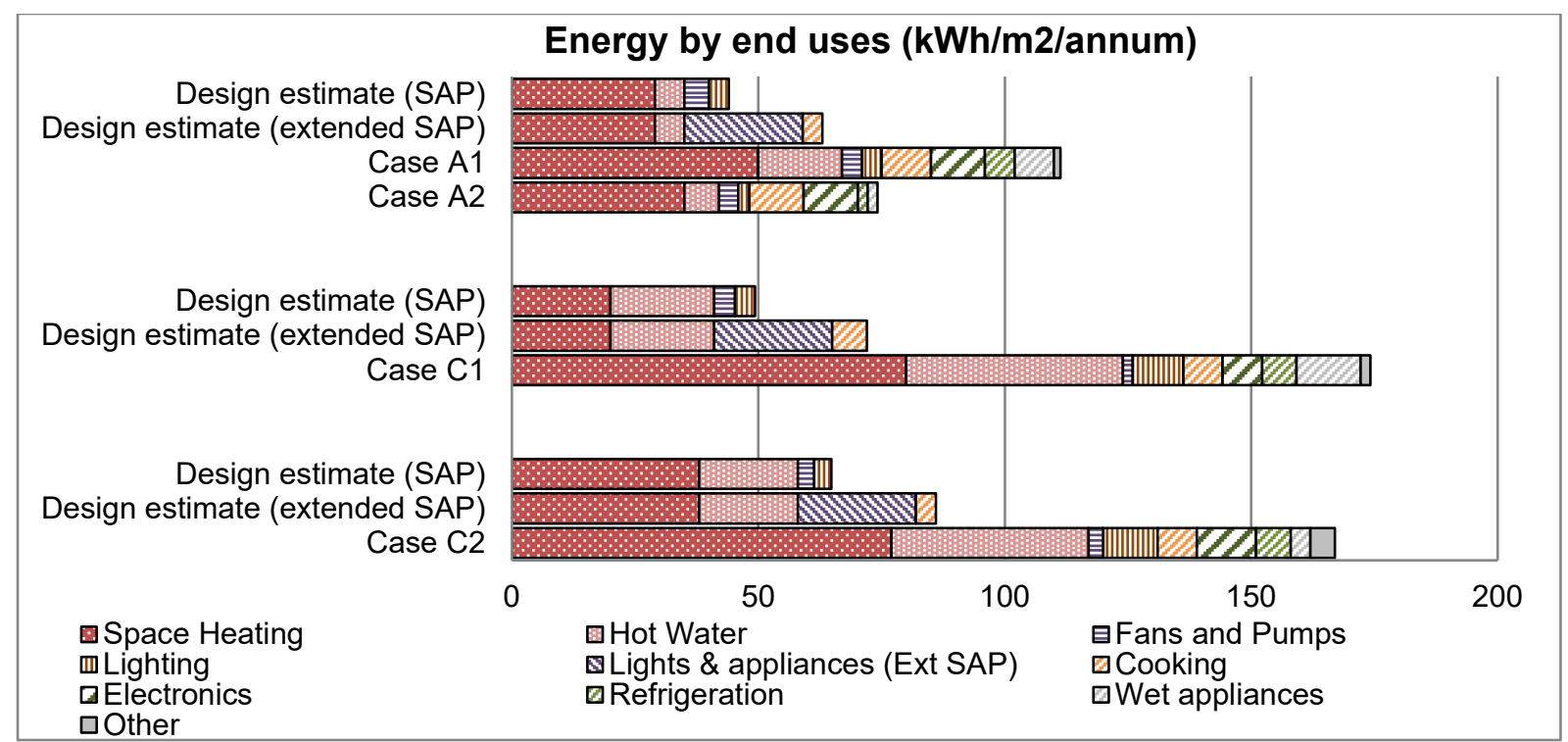

Figure 3 Energy by end uses (January 2013-December 2013).

Due to all the aforementioned issues, actual fuel bills across all case study houses were very high, despite the developments being designed to reduce energy use and fuel bills. As shown in Figure 4, fuel bills of five out of the six case studies were even higher than a typical household in UK (Ofgem 2013), and interestingly, much above the SAP estimated cost (between 4 and 12 times) questioning the use of compliance tools (such as SAP) for 
decision-making by housing associations. It should be noted that estimated annual costs rose significantly when taking into account the energy use of appliances, as done in the extended SAP calculation.

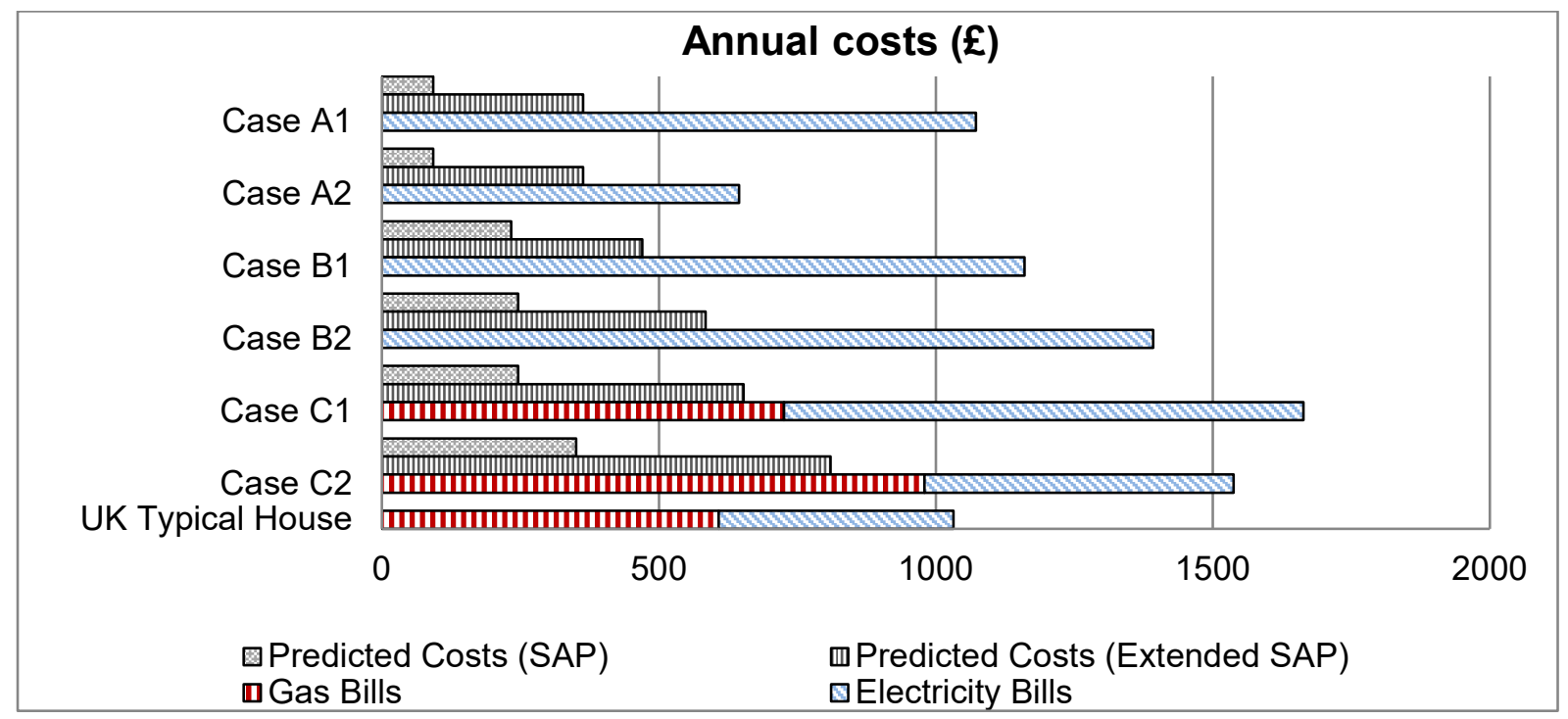

Figure 4 Annual energy costs (January 2013-December 2013). Typical UK domestic energy bills were based on average household bills (Ofgem, 2013). (For SAP, extended SAP and actual energy use, PV export compensation was taken into account. However, it should be noted that social housing tenants did not receive any feed-back tariffs that go directly to the social housing provider)

Interestingly occupants also attributed their high electricity bills to frequent breakdowns of the MVHR systems (all three developments), poor performance of the heat pumps and alwayson under-floor central heating system (Developments A and B). This was why in case B1 occupants turned off the MVHR system and underfloor heating to save on the fuel costs, without realising the unintended consequences on indoor environmental conditions and health. Such inadvertent actions by residents could become commonplace if the fabric and system performance of low energy homes is not improved.

\section{Indoor environment}

Occupant expectations and perception of comfort had a direct impact on indoor environmental conditions. Indoor temperature was recorded in the living room (and bedroom) spaces of the case study dwellings during the monitoring period (January 2013 - December 2013). Mean winter temperatures ranged between $20-24{ }^{\circ} \mathrm{C}$ across the houses, with three out of six dwellings having mean living room temperatures $>22{ }^{\circ} \mathrm{C}$ (Figure 5). Peak winter temperatures $>26{ }^{\circ} \mathrm{C}$ were observed in the majority of the living rooms (four out of six). Analysis showed that in most cases, winter temperatures in living rooms exceed $26{ }^{\circ} \mathrm{C}$ for less than $1 \%$ of the occupied hours (daytime), but in Cases A2 and C1, this occurred 1.2 and $2.4 \%$ respectively, indicating that these living rooms are very warm even during the heating season (Figure 6). Mean summer temperatures ranged between $21-24^{\circ} \mathrm{C}$, with four out of six houses experiencing max living room temperatures in summer above $27^{\circ} \mathrm{C}$. In all Cases, with the exception of Case B1, summer living room temperatures exceed $28{ }^{\circ} \mathrm{C}$ for more than $1 \%$ of occupied hours. In Cases $\mathrm{C} 2$ and $\mathrm{A} 1$ in particular summer living room temperatures 
remained above $28{ }^{\circ} \mathrm{C}$ for $4 \%$ and $4.75 \%$ of occupied hours respectively, indicating risk of overheating (Figure 7).

Living Room Temperature (min,mean, $\left.\max { }^{\circ} \mathrm{C}\right) \mid$ October-April

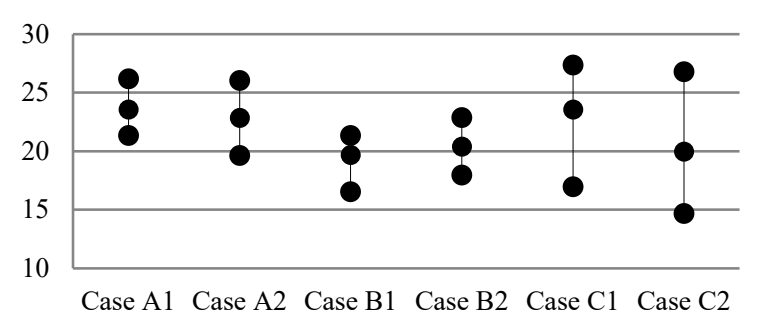

Living Room Temperature (min,mean, $\left.\max { }^{\circ} \mathrm{C}\right) \mid$ May-Sept

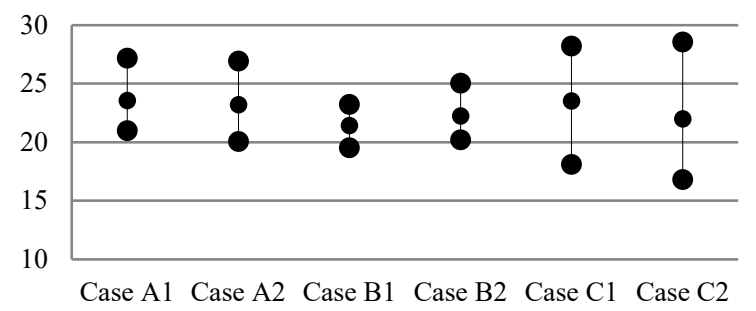

Figure 5 Minimum, mean and maximum temperatures in living rooms during the heating and non-heating periods.
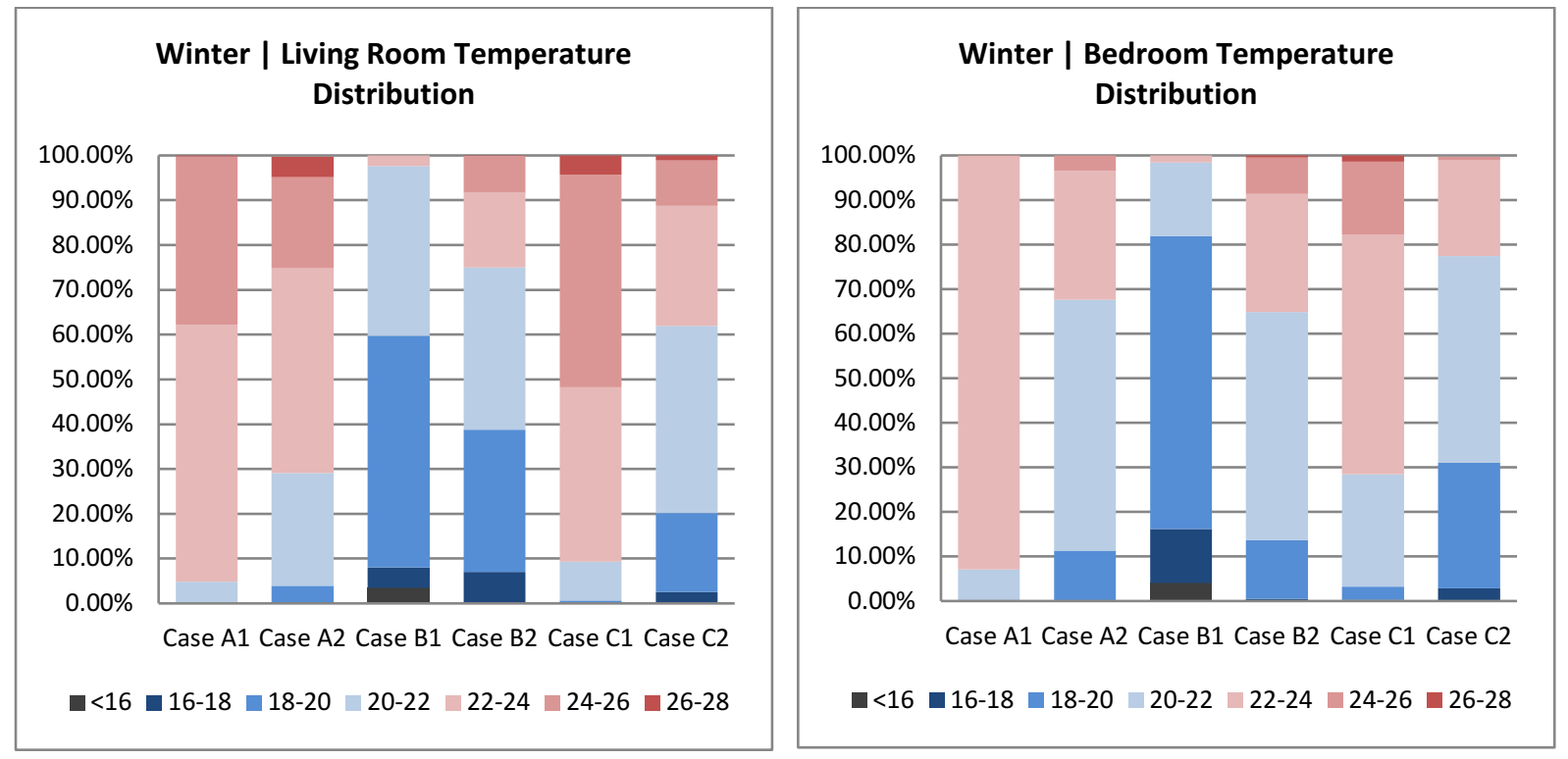

Figure 6 Temperature distributions in living rooms and bedrooms during the heating period (January-April 2013 and October -December 2013) 

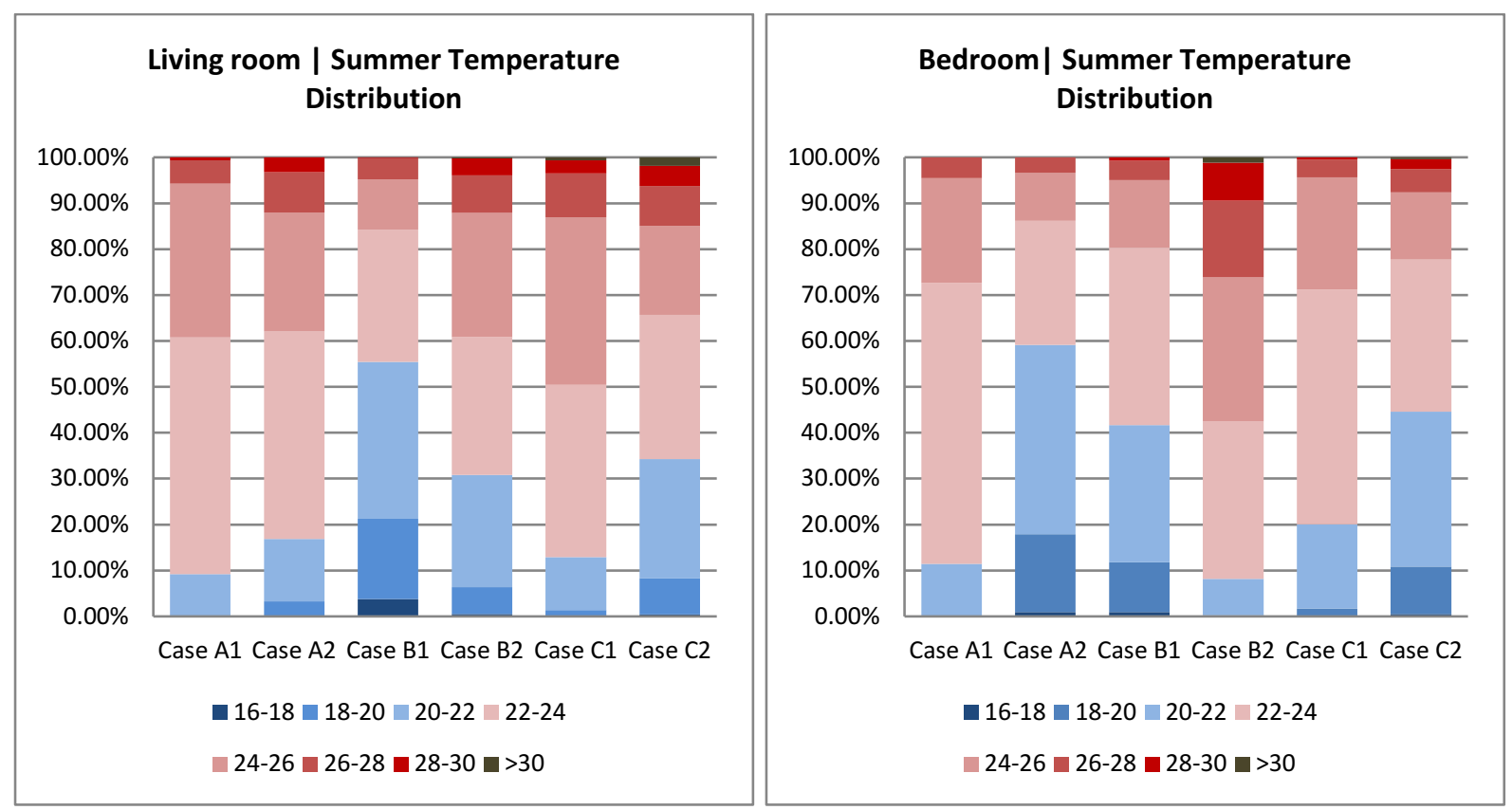

Figure 7 Temperature distributions in living rooms and bedrooms during the non-heating period (May-September 2013)

Figure 8 shows the average hourly temperatures and $\mathrm{RH}$ levels recorded in the living rooms of the six case study houses during January and August. The lowest winter temperatures were recorded in Cases B1 and B2, often falling below the suggested EN15251 comfort levels of $20-26{ }^{\circ} \mathrm{C}$ (CEN, 2007). Case B1 had the lowest mean winter temperatures due to occupant's efforts to minimize their electricity bills by heating their house during the night only. Cases $\mathrm{A} 1$ and $\mathrm{C} 1$ had the highest winter temperatures as they kept their thermostats at around $25-27{ }^{\circ} \mathrm{C}$ throughout the day. Summer temperatures ranged between $21-26{ }^{\circ} \mathrm{C}$ in most cases, with the exception of Case C2 that presented the greatest scatter during both winter and summer, with summer temperatures often exceeding $27^{\circ} \mathrm{C}$ and reaching $29^{\circ} \mathrm{C}$ at times. Low winter temperatures recorded in Case C2 were due to prolonged window opening. High indoor temperatures were affecting internal relative humidity $(\mathrm{RH})$ levels, which in general were quite low; less than $50 \%$ in the heating season (October-April) and less than $60 \%$ in the non-heating season (May-September) in most cases. In the non-heating season both $\mathrm{RH}$ levels and temperatures increased, but remained inside the CIBSE recommended comfort limits of $40-70 \%$ (CIBSE, 2006).
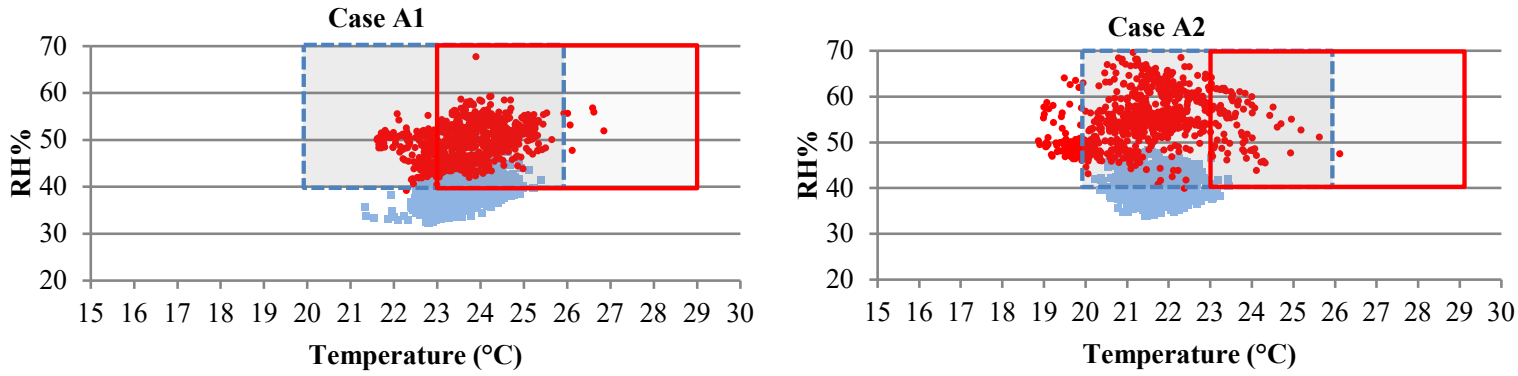

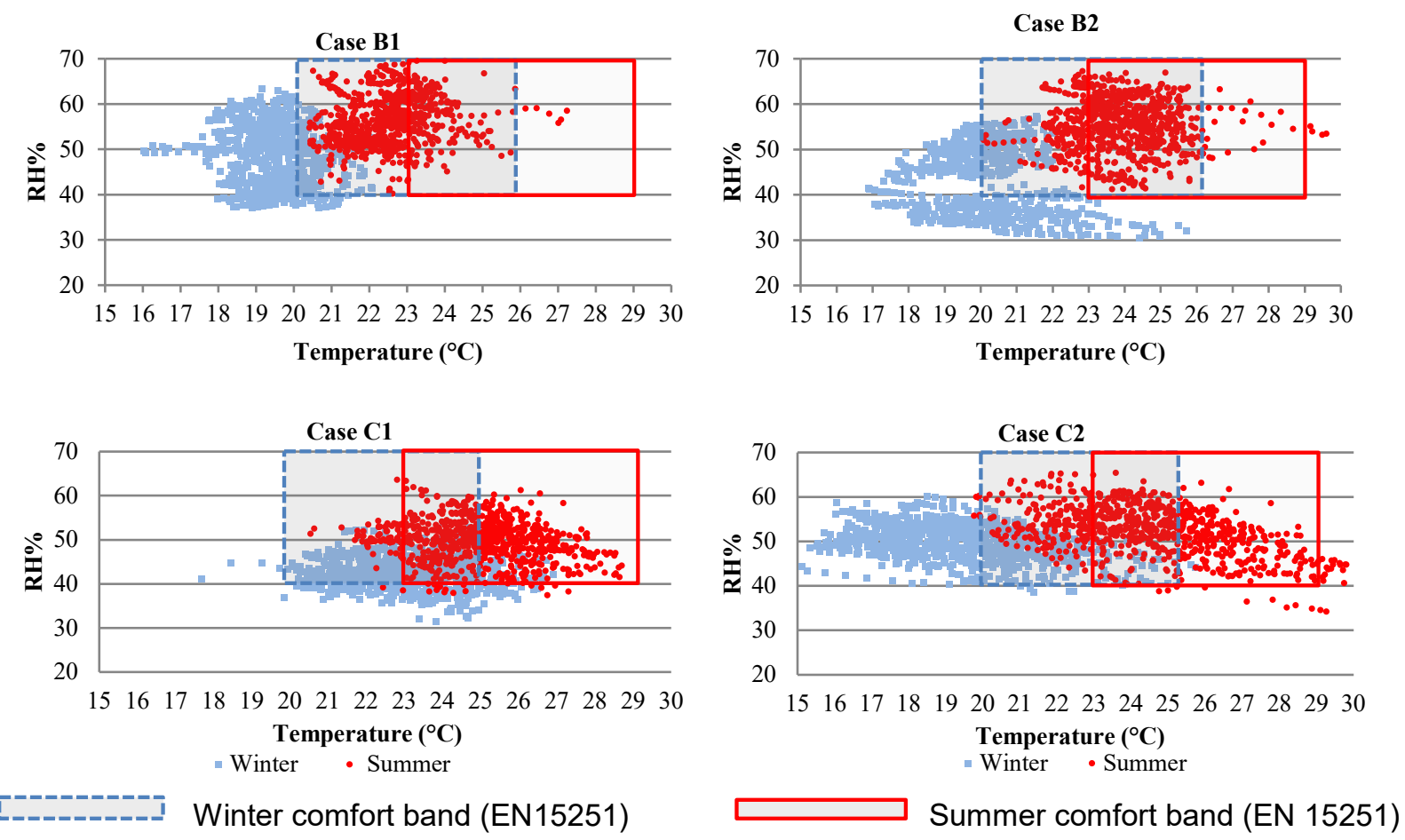

Figure 8 Average hourly temperature and relative humidity levels during winter (January) and summer (August).

Figures 9 and 10 show the average monthly temperature and $\mathrm{RH}$ in living rooms respectively. Average monthly temperatures ranged between $19-25^{\circ} \mathrm{C}$ across all cases, with the lowest temperatures recorded in Cases B1 and C2. RH levels ranged between $25-60 \%$, with the lowest levels recorded in Case A2 which also presented the highest temperatures during winter months (February-March). 


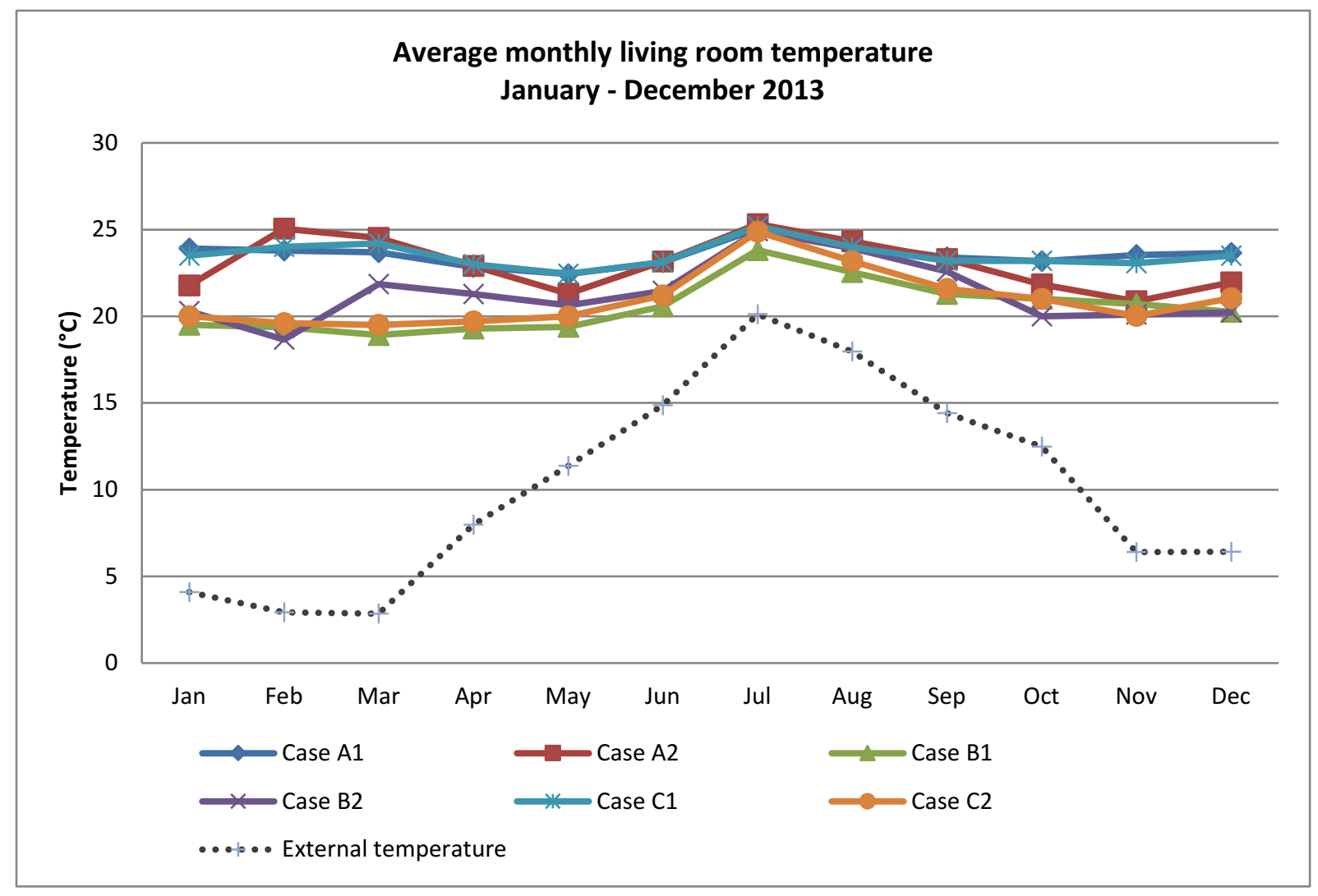

Figure 9 Average monthly living room temperature (January-December 2013)

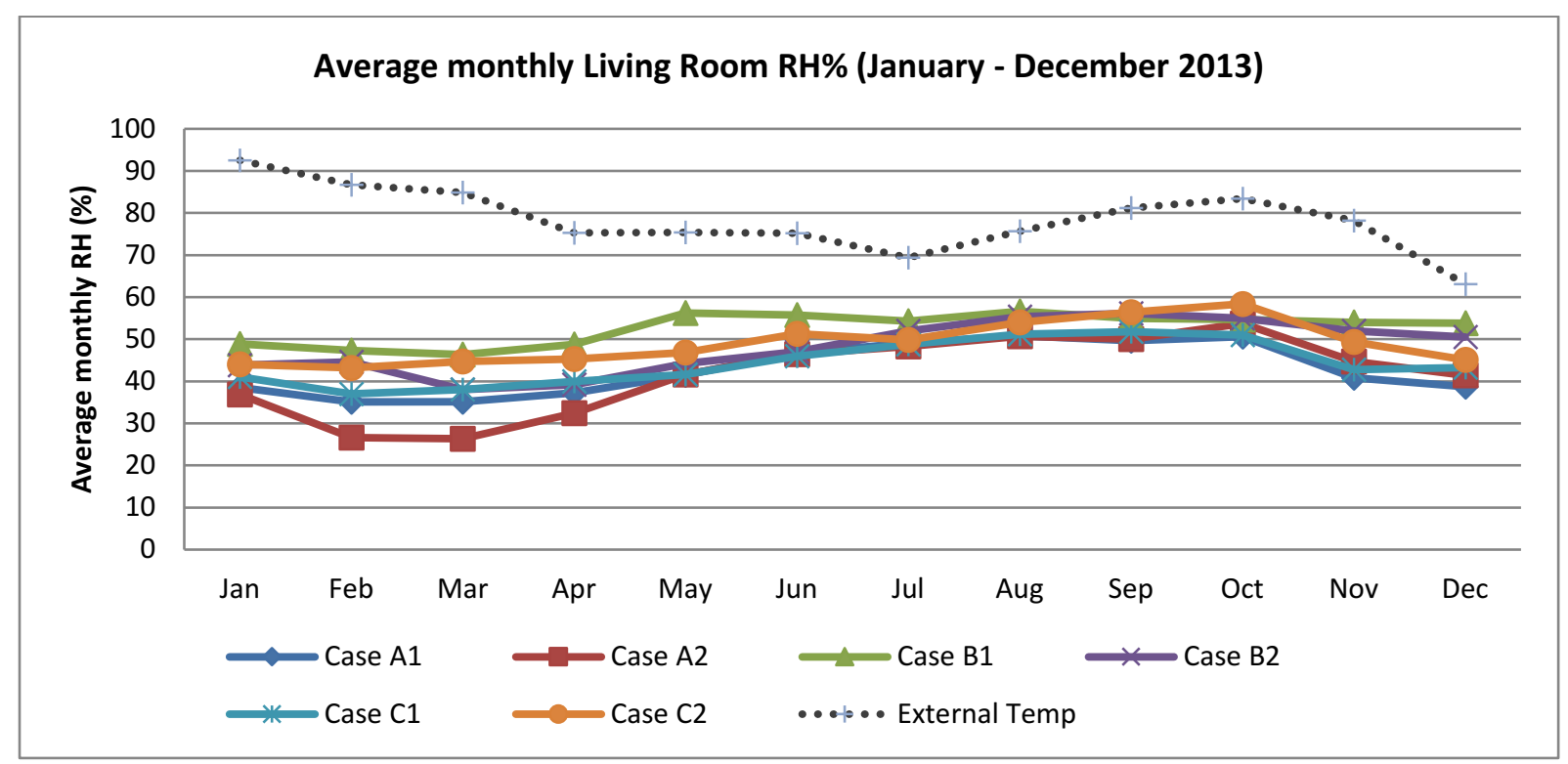

Figure 10 Average monthly RH in living rooms (January-December 2013)

Findings from occupant surveys and interviews helped to contextualise the environmental conditions in the houses. In Developments A and B, temperatures during winter were generally regarded as quite comfortable, whereas summer temperatures were perceived as slightly hot. In both developments occupants complained of poor control over heating with 
some occupants feeling they could not control temperatures effectively. Complaints of high summer temperatures in Developments $A$ and $B$ indicated that the houses were not adaptable to warm weather conditions. This may have been due to the lack of shading devices, lack of cross ventilation and low thermal mass of the houses. Interestingly, in Development $C$ both summer and winter temperatures were perceived as comfortable from the majority of the occupants despite the fact that the two case studies from Development $C$ presented the highest indoor temperatures across all six case studies. These findings indicated that the perception of comfort varied greatly between different occupants.

The open-close state of the principal windows in living room and bedroom spaces of four case study houses (A1, A2, C1 and C2) were also monitored concurrently with environmental conditions to better understand the relationship between human interactions and the physical environment of homes. The hourly percentage of window opening in living rooms and bedrooms for the heating season has been plotted against hourly average internal temperatures, as shown in Figure 11. During the heating season occupants in Cases A1 and A2 tended to keep their windows mostly closed and indoor hourly temperatures were kept steady throughout the day. Conversely, indoor temperatures in C1 and C2 presented a higher diurnal variation as occupants left their windows open for longer periods. While in $\mathrm{C} 1$ occupants tended to open the living room window and backdoor when indoor temperatures rose, in Case C2 occupants left the living room window open throughout the day. This habitual behaviour might explain the high energy usage of cases $\mathrm{C} 1$ and $\mathrm{C} 2$.
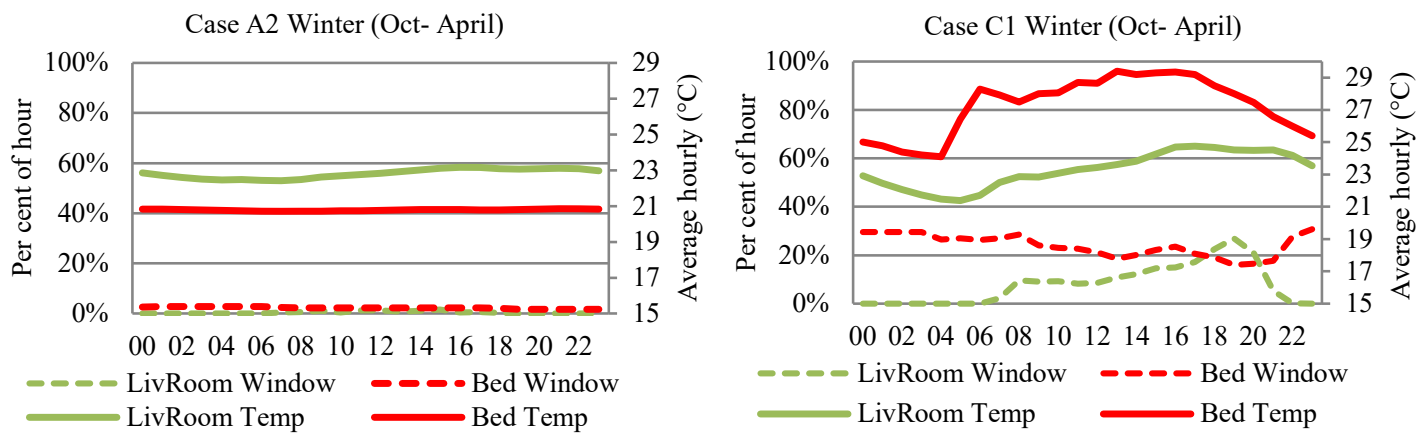

Figure 11 Hourly average temperatures and hourly percentage of window opening over a day

Window opening in Cases $\mathrm{A} 1, \mathrm{~A} 2, \mathrm{C} 1$ and $\mathrm{C} 2$ was also correlated with $\mathrm{CO}_{2}$ levels in the living rooms and bedrooms. Levels of $\mathrm{CO}_{2}$ correlated well with human occupancy and human-generated pollutants and provided a useful indicator of relative levels of ventilation and indoor air quality. It is generally accepted that levels above $1000 \mathrm{ppm}$ are indicative of poor air quality and ventilation rates (Porteous, 2011), which corresponds to a ventilation rate of $8 \mathrm{l} / \mathrm{s}$ per person. Occupants in Cases C1 and C2 had manually overridden the MVHR systems (discussed in following section) and were relying on window opening to ventilate their houses. The effect of this can be seen in Figure 12. $\mathrm{CO}_{2}$ levels during sleeping hours were much higher in $\mathrm{C} 1$ bedroom compared to A2 bedroom that had the same occupancy (2 adults) but was also less airtight. There appeared to be a correlation between the high $\mathrm{CO}_{2}$ levels and window opening in Case $\mathrm{C} 2$, as occupants tended to keep the bedroom window open during the night and also open the living room window in the afternoon, both during times when $\mathrm{CO}_{2}$ levels are elevated. 

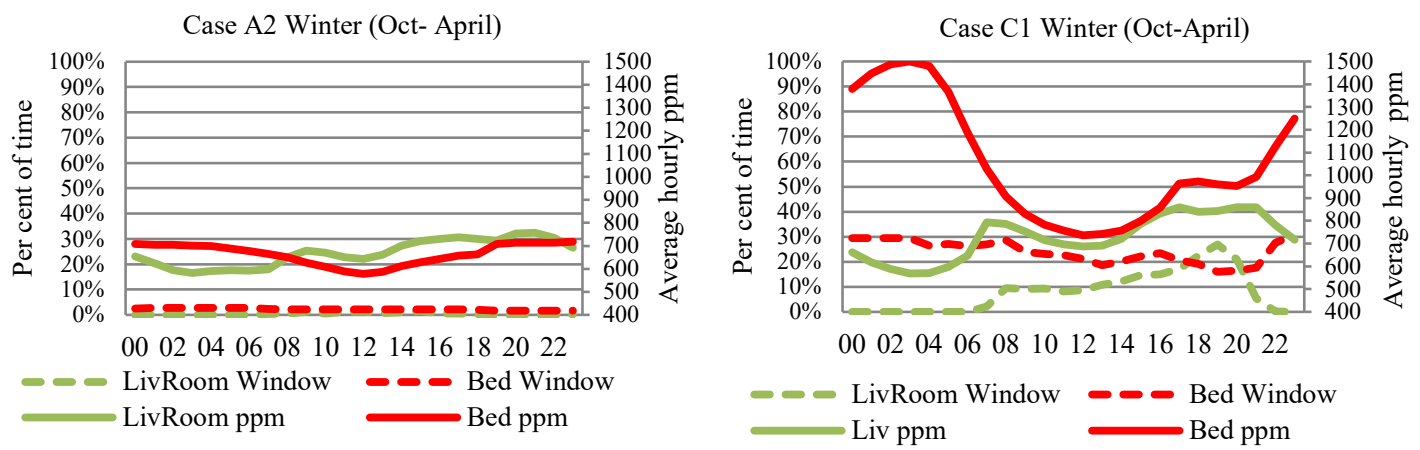

Figure 12 Hourly average $\mathrm{CO}_{2}$ levels and hourly percentage of window opening across a day

The amount of time $\mathrm{CO}_{2}$ levels were above the limit of $1000 \mathrm{ppm}$ during a year in each of the four case study houses is graphed in Figure 13.
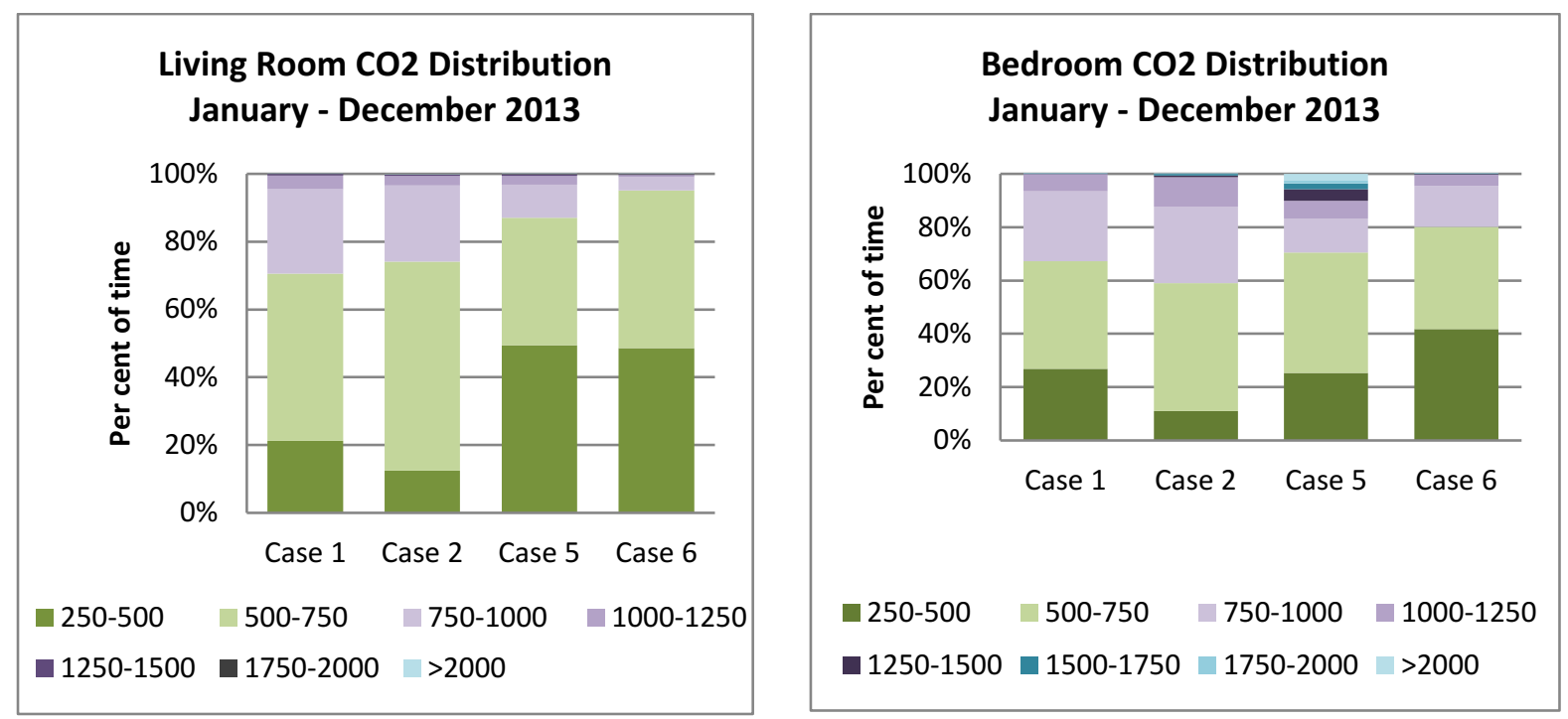

Figure 13 Distribution of $\mathrm{CO}_{2}$ levels in living rooms and bedrooms (Jan - Dec 2013).

While in Cases $\mathrm{A} 1$ and $\mathrm{A} 2, \mathrm{CO}_{2}$ levels in the living rooms ranged between $500-750 \mathrm{ppm}$ for the majority of the time (50-60\%); $\mathrm{CO}_{2}$ levels were lower in Cases $\mathrm{C} 1$ and $\mathrm{C} 2$ living rooms remaining $<500 \mathrm{ppm}$ for $50 \%$ of the time. This was directly related to the window opening behaviour as occupants in Cases $\mathrm{C} 1$ and $\mathrm{C} 2$ habitually opened their windows more frequently than occupants in Cases $\mathrm{A} 1$ and $\mathrm{A} 2$. Despite this, living room $\mathrm{CO}_{2}$ levels in Cases $\mathrm{A} 1, \mathrm{~A} 2$ and $\mathrm{C} 1$, levels exceeded $1000 \mathrm{ppm}$ for $3-4 \%$ of the time, while bedroom $\mathrm{CO}_{2}$ levels exceed 1000 ppm for $4-6 \%$ of the time in Cases $A 1$ and C2, and for $12-17 \%$ of the time in Cases $\mathrm{A} 2$ and $\mathrm{C} 1$. High bedroom $\mathrm{CO}_{2}$ levels in Cases $\mathrm{A} 2$ and $\mathrm{C} 1$ were partly due to room occupancy levels (2 occupants per room during the night). The differences between living room and bedroom $\mathrm{CO}_{2}$ levels implied that ventilation rates were not adequate when occupants were asleep (and opportunities for adaptive control were limited), particularly when the MVHR is not working properly. 


\section{Discussion}

There is clear evidence that actual energy use and environmental performance of low energy social housing is affected by the interdependencies between physical performance of the fabric, services and systems as well as the occupants' understanding of the systems, expectations and perception of comfort and their habitual behaviours. Issues such as higher than predicted heat losses, that occur through higher than expected air permeability levels and un-balanced MVHR systems, combined with poor commissioning of systems and underperformance of the low-carbon technologies (MVHR and heat pumps), limited control and lack of knowledge on the daily and seasonal operation of systems due to poor or confusing guidance, as well as occupant behaviour and habits, resulted in poor use of systems and increased energy use.

Conflicting, confusing and non-intuitive heating controls has led to poor occupant control over heating. Such unusable systems and strategies make occupants sceptical towards them and can elicit different reactions from different occupants who may often look for ways to override the systems at the expense of energy use and environmental conditions. However, the reality was that most occupants were doing the best they can with limited knowledge of uncoordinated and inefficient systems. For houses to perform as intended it is important to tackle these issues right from the design stage through to specification, construction, handover and operation.

There is a need for integrating the heating and ventilation systems and controls strategy early in the design process, to provide a simpler approach that occupants can understand and operate more easily (BSRIA, 2014). More robust and effective ventilation strategies should be designed and integrated with the heating systems to have closer control of heat delivery. Seasonal commissioning (at least in summer and winter) of services and systems should be undertaken for new low energy houses especially with mechanical ventilation systems and technologies such as heat pumps.

Control interfaces need to be intuitive, clearly labelled and properly designed, and installed in an accessible location. Occupants need to be trained through graduated and extended handover that involves occupants trying out systems and controls in the presence of trained housing officers, supplemented by visual home user guides offering clear guidance on the daily and seasonal operation of systems and controls. This also highlights the need for redefining the role of housing or tenant liaison officers (of Housing Associations) in engaging with social housing tenants to manage their expectations and also re-training them for summer and winter operations of their low energy homes. Further research is required to understand the impact of such deeper engagement on occupant understanding and operation of services and systems. Findings from the study also point to the need for having an open discussion amongst industry, Government and academia in order to understand deeper, the balance between ventilation and airtightness levels in low energy dwellings for achieving good levels of indoor air quality.

\section{Conclusions}

The study has not only highlighted issues of underperformance of fabric, services and systems in low energy social housing, but also shown how BPE-based approach can help to identify faults that would otherwise go unnoticed and become serious issues. With requirements for as-built performance likely to be included in future Building Regulations, the 
importance of achieving real performance that matches predictions is becoming a mainstream issue $(\mathrm{ZCH}, 2013)$. Wider lessons are drawn from the study for policy makers, industry and academia:

- As highlighted by the review of fabric performance, robust detailing of joints, junctions and thresholds should be carefully followed during design and construction stages. Weaknesses in thermal performance of building fabric can be picked up using a combination of diagnostic techniques especially for early detection of problems (Gupta and Kotopouleas, 2018).

- Accurate 'as-built' energy models should become mandatory and be enforced rigorously for all projects of all scales to record design and procurement changes that affect energy performance. This would involve updating SAP models using 'as-built' data to gain a better understanding of the expected performance of the building.

- Proper documentation of housing performance should be enforced. Commissioning records of services and systems should be used to check the performance of heating and ventilation systems through seasonal commissioning.

- Good sub-metering data can provide deep insights for residents and developers, as to how and why energy is used and wasted. Arrangements for sub-metering domestic energy use should be carefully considered during the design stage.

Without this level and depth of evaluation, the gap between designed and actual energy use could widen and Government national $\mathrm{CO}_{2}$ targets could be compromised.

\section{Acknowledgements}

We are grateful to UK Government's Technology Strategy Board's (now innovate UK) Building Performance Evaluation programme for funding this research project. Our sincere thanks to the occupants, clients and project design teams for their help and support during the study.

\section{References}

Almeida, R.M.S.F., Ramos, N.M.M., Pereira, P.F., 2017. A contribution for the quantification of the influence of windows on the airtightness of Southern European buildings. Energy Build, 139 (2017), pp. 174-185

Behar, C., Chiu L.F., 2013.Ventilation in energy efficient UK homes: A user experience of innovative technologies. ECEEE 2014 Summer Study Conference Proc.

Boardman, B., 2007. Home Truths: A low-carbon strategy to reduce UK housing emissions by $80 \%$ by 2050 . http://www.foe.co.uk/sites/default/files/downloads/home_truths.pdf

Bordass, B., Leaman, A., Bunn, R., 2007. Controls for End Users: A guide for good design and implementations, Building Controls Industry Association (BCIA), www.bsria.co.uk

Bramiana, C.N., Entrop, A.G., Halman, J.I.M., 2016. Relationships between building characteristics and airtightness of Dutch dwellings. Energy Procedia, 96 (2016), pp. 580-591 
BSRIA, 2014. The Soft Landings Framework for better briefing, design, handover and building performance in-use. Retrieved from https://www.bsria.co.uk

CEN Standard EN15251, 2007. Indoor environmental input parameters for design and assessment of energy performance of buildings addressing indoor air quality, thermal environment, lighting and acoustics Bruxelles: European committee for Standardisation

Chartered Institution of Building Services Engineers (CIBSE), 2006. Guide A: Environmental design. London, CIBSE.

CIBSE, 2000. TM 23, Testing Buildings for Air Leakage. CIBSE, London

Davies, M., Oreszczyn, T., 2012. The unintended consequences of decarbonising the built environment: A UK case study, Energy and Buildings, Volume 46, March 2012, Pages 80-85

Department for Communities and Local Government (DCLG), 2009. Definition of Zero Carbon Homes: Impact Assessment www.communities.gov.uk/publications/planningandbuilding/impactzerocarbon

DCLG, 2014. Affordable housing supply in England: 2013 to 2014.Department for Communities and Local Government.

Department of Energy and Climate Change, 2013. United Kingdom housing energy fact file 2013. DECC; December 2013.

Energy Saving Trust, 2009. Enhanced construction details: thermal bridging and airtightness, CE302; October 2009.

Energy Savings Trust (EST), 2010. Ventilation and Airtightness in New Homes. www.energysavingtrust.org.uk

Energy Saving Trust (EST), 2013. Detailed analysis from the second phase of the Energy Saving Trust's heat pump field trial. https://www.gov.uk

European Commission (2011). Communication from the commission to the European Parliament, the council, the European economic and social committee and the committee of the regions a roadmap for moving to a competitive low carbon economy in 2050.

http://eurlex.europa.eu/LexUriServ/LexUriServ.do?uri=CELEX:52011DC0112:EN:NO $\mathrm{T}$.

European Union (EU), 2010. Directive 2010/31/EU of the European Parliament and of the council of 19 May 2010 on the energy performance of buildings 2010 http://ec.europa.eu/energy/efficiency/buildings/buildings_en.html

Firth, S., Lomas, K., Wright, A., Wall, R. 2008. Identifying trends in the use of domestic appliances from household electricity consumption measurements. Energy and Buildings, 40, 926-936. doi: 10.1016/j.enbuild.2007.07.005 
Gaze, C., 2014(a). AIMC4 Information paper 5: lessons from AIMC4 for cost-effective fabricfirst low-energy housing Part 5: As-Built performance and Post Occupancy Evaluation.

Gaze, C., 2014(b). How did the homes perform? The data. Paper presented at the Proceedings of final AIMC4 conference.

Gill, Z.M., Tierney, M.J., Pegg I.M., and N. Allan, N. 2010. Low energy dwellings: the contribution of behaviours to actual performance. Building Research and Information, $38: 5,491-508$.

Good Homes Alliance, 2014. Community in a cube: riverside one case study; 2014.

Gram-Hanssen, K., 2010. Residential heat comfort practices: understanding users, Build Res Inform, 38 (2), pp. 175-186

Guerra-Santin, O., Tweed, C., Jenkins, H., Jiang, S., 2013. Monitoring the performance of low energy dwellings: two UK case studies. Energy Build, 64 (2013), pp. 32-40

Gupta R., Gregg, M., Cherian,R., 2013. Tackling the performance gap between design intent and actual outcomes of new low/zero carbon housing, ECEEE 2013 Summer Study proceedings, France, 1-6 June 2013.

Gupta, R., Kapsali, M., 2014. How effective are 'close to zero' carbon new dwellings in reducing actual energy demand: Insights from UK. PLEA Conference Proc., Ahmedabad, India

Gupta, R. and Kotopouleas, A. (2018 Magnitude and extent of building fabric thermal performance gap in UK low energy housing, Applied Energy, 222, 673-686n

HMG, 2008. Climate Change Act 2008, HMSO 12/2008 41543519585

Huebner, G. M., Hamilton, I., Chalabi, Z., Shipworth, D. \& Oreszczyn, T., 2015. Explaining domestic energy consumption - The comparative contribution of building factors, socio-demographics, behaviours and attitudes. Applied Energy, 159, 589-600.

Johnston, D., Farmer, D., Brooke-Peat, M., Miles-Shenton, D., 2016. Bridging the domestic building fabric performance gap. Build Res Inform, 44 (2) (2016), pp. 147-159

Jokisalo, J., Kurnitski, J., Korpi, M., Kalamees, T., Vinha, J., 2009. Building leakage, infiltration, and energy performance analyses for Finnish detached houses. Build Environ, 44 (2009), pp. 377-387

Jones, R.V., Lomas, K.J., 2015. Determinants of high electrical energy demand in UK homes: socio-economic and dwelling characteristics, Energy Build, 101, pp. 24-34

Kalamees, T., 2007. Air tightness and air leakages of new lightweight single-family detached houses in Estonia. Build Environ, 42 (2007), pp. 2369-2377 
Medina, H., Lowe, R., \& Eaton, C., 2014. GHA Monitoring programme 2011-2013: technical report (One Brighton). London

Monahan, S. \& Gemmell, A., 2011. How occupants behave and interact with their homes: The impact on energy use, comfort, control and satisfaction, Milton Keynes: NHBC Foundation.

NEF, 2015. Insights from Social Housing Projects - Building Performance Evaluation MetaAnalysis, Executive Report for Innovate UK. Milton Keynes: National Energy Foundation

Ofgem, 2013. Review of typical domestic consumption values. https://www.ofgem.gov.uk/ofgem-publications/74735/tdcv-review-consultation.pdf

Palmer, J., Godoy-Shimizu, D., Tillson, A., \& Mawditt, I., 2016. Building Performance Evaluation Programme: Findings from domestic projects Making reality match design. Innovate UK.

Pan, W., 2010. Relationships between air-tightness and its influencing factors of post-2006 new-build dwellings in the UK, Build Environ, 45 (2010), pp. 2387-2399

Porteous, C., 2011. Sensing a historic low- $\mathrm{CO}_{2}$ future. In: Mazzeo (Ed.) Chemistry, emission control, radioactive pollution and indoor air quality. Croatia: Intech. Retrieved from http://www.intechopen.com

Preiser, W., Vischer, J., 2005. Assessing Building Performance, Elsevier, Butterworth, Heinemann

Price S., Brown H., 2012. Mechanical Ventilation with Heat Recovery: Designing and implementing a robust and effective ventilation system. http://www.encraft.co.uk

Ridley, I., Bere, J., Clarke, A., Schwartz, Y. \& Farr, A., 2014. The side by side in use monitored performance of two passive and low carbon Welsh houses. Energy and Buildings, 82, 13-26.Available:

http://www.sciencedirect.com/science/article/pii/S0378778814005209

Sfakianaki, A., Pavlou, K., Santamouris, M., Livada, I., Assimakopoulos, M.N., Mantas, P. et al., 2008. Air tightness measurements of residential houses in Athens, Greece, Build Environ, 43 (2008), pp. 398-405

Sharpe, T., Shearer, D., 2013. "Scenario testing of the energy and environmental performance of the Glasgow House." PLEA 29th Conference, Munich, Germany, September 10-12.

Sinnott, D., 2016. Dwelling airtightness: a socio-technical evaluation in an Irish context, Build Environ, 95 (2016), pp. 264-271

Steemers, K. and G.Y Yun. 2009. Household energy consumption: a study of the role of occupants. Building Research and Information, 37(5-6), 625-637. 
Stevenson, F., Rijal, H.B., 2010. Developing occupancy feedback from a prototype to improve housing production, Building Research \& Information, 38:5, doi: 549-563, 10.1080/09613218.2010.497282

Thompson, P., Bootland, J., 2011. "GHA monitoring programme 2009-11: Technical report. Results from Phase 1: Post-construction testing of a sample of highly sustainable new homes". Good Homes Alliance. http://www.goodhomes.org.uk/downloads

Topouzi, M., 2013. Low-carbon refurbishments: How passive or active are technologies, users and their interaction?, ECEEE 2013 Summer Study proceedings, France, 1-6 June 2013.

TSB (Technology Strategy Board), 2012. Competition: Building Performance Evaluation webpage, http://www.innovateuk.org

UKGBC (United Kingdom Green Building Council), 2008. The definition of zero carbon, Zero Carbon Task Group report.

Vinha, J., Manelius, E., Korpi, M., Salminen, K., Kurnitski, J., Kiviste, M. et al., 2015. Airtightness of residential buildings in Finland, Build Environ, 93 (2) (2015), pp. 128140

Wingfield, J., Bell, M., Miles-Shenton, D., Seavers, J., 2011. Elm Tree Mews Field Trial. CeBE Report http://www.leedsmet.ac.uk/as/cebe/projects/elmtree

Wingfield, J., Bell, M., Miles-Shenton, D., South, T., \& Lowe, R., 2008. Evaluating the impact of an enhanced energy performance standard on load-bearing masonry domestic construction: Understanding the gap between designed and real performance: lessons from Stamford Brook.

Zero Carbon Hub, 2013. Closing the gap between designed and as-built performance. http://www.zerocarbonhub.org

Zero Carbon Hub, 2014. Closing the gap between design and as-built performance. End of term report.

Zero Carbon Hub, 2016. Thermal bridging guide - an introduction to thermal bridging in homes, London; February 2016.

\footnotetext{
i Standard Assessment Procedure (SAP) is the methodology used by the Government to assess and compare the energy and environmental performance of dwellings. Its purpose is to provide accurate and reliable assessments of dwelling energy performances that are needed to underpin energy and environmental policy initiatives. SAP works by assessing how much energy a dwelling will consume, when delivering a defined level of comfort and service provision. The assessment is based on standardised assumptions for occupancy and behaviour. This enables a like-for-like comparison of dwelling performance.

ii Air permeability is a measure of the air tightness of the building associated with the uncontrolled infiltration or loss of air through cracks and gaps in the building fabric. It is defined as air leakage rate per hour per square metre of envelope area at a test reference pressure differential across the building envelope of 50 Pascal. The test involves the pressurisation (or depressurisation) of the building by means of variable speed fan(s) installed to a suitable external opening while the remaining openings are closed and vents are shut or sealed. The resulting
} 
difference between the external and internal pressure is used to calculate the permeability of the building envelope. Beyond the basic method, the test can be extended to include both pressurisation and depressurisation (in this case the final result is the average of the two values) and smoke test for the identification of air leakage pathways. In England, Wales and Northern Ireland the pressurisation testing of dwellings is a standard requirement of the Building Regulations since 2006 which currently set airtightness limit of $10 \mathrm{~m}^{3} / \mathrm{h} / \mathrm{m}^{2} @ 50 \mathrm{~Pa}$, while in 2010 became mandatory also in Scotland.

iii Thermal transmittance measurements $\left(\mathrm{W} / \mathrm{m}^{2} \mathrm{~K}\right)$ assess the effectiveness of specific elements of the building fabric as insulators. In-situ measurements are carried out with heat flux sensors that provide a direct measure of the heat flux from a surface through a construction element. The method, detailed in ISO 9869 [58], can be used to determine the U-value of individual construction materials or the U-value of building elements comprising several layers. Its value lies in providing data that enables investigative examination of a range of heat loss mechanisms and can be particularly useful if undertaken in conjunction with whole house heat loss measurement. iv Infrared thermography is conducted using a handheld thermal camera which depicts the intensity of infrared radiation emitted by the surfaces and therefore the heat differential of objects in the view based on the materials emission values. The technique, is often used as a diagnostic tool to identify anomalies in construction which may be the result of gaps in insulation layers, different insulation characteristics, air movement within the structure, or more usually a combination of all three

iii Code for Sustainable Homes (CSH) is a voluntray UK national standard for rating and certifying the performance of new homes. $\mathrm{CSH}$ covers nine categories of sustainable design (Energy/ $\mathrm{CO}_{2}$ emissions; water; materials; surface water run-off; waste; pollution; health and well-being; management; ecology), within which points are awarded for good environmental practice. Points are converted into a six-point rating scale, where Level 3 is equivalent to building regulations, Levels 4 and 5 represent exceeding building regulations and Level 6 represents net zero $\mathrm{CO}_{2}$ emissions. 